\title{
Article \\ Terminal and Internal Alkyne Complexes and Azide-Alkyne Cycloaddition Chemistry of Copper(I) Supported by a Fluorinated Bis(pyrazolyl)borate
}

\author{
Anurag Noonikara-Poyil ${ }^{1}$, Alvaro Muñoz-Castro ${ }^{2, *}$ and H. V. Rasika Dias ${ }^{1, *}$ \\ 1 Department of Chemistry and Biochemistry, The University of Texas at Arlington, Arlington, TX 76019, USA \\ anurag.noonikarapoyil@mavs.uta.edu \\ 2 Grupo de Química Inorgánica y Materiales Moleculares, Facultad de Ingenieria, Universidad Autonoma de \\ Chile, El Llano Subercaseaux 2801, Santiago 8910060, Chile \\ * Correspondence: alvaro.munoz@uautonoma.cl (A.M.-C.); dias@uta.edu (H.V.R.D.)
}

check for

updates

Citation: Noonikara-Poyil, A.;

Muñoz-Castro, A.; Dias, H.V.R

Terminal and Internal Alkyne Complexes and Azide-Alkyne Cycloaddition Chemistry of Copper(I) Supported by a Fluorinated Bis(pyrazolyl)borate. Molecules 2022, 27, 16. https:// doi.org/10.3390/molecules27010016

Academic Editors: Joice Thomas, Nithya Joseph and Dmitry Eremin

Received: 7 December 2021

Accepted: 18 December 2021

Published: 21 December 2021

Publisher's Note: MDPI stays neutral with regard to jurisdictional claims in published maps and institutional affiliations.

Copyright: (C) 2021 by the authors. Licensee MDPI, Basel, Switzerland. This article is an open access article distributed under the terms and conditions of the Creative Commons Attribution (CC BY) license (https:// creativecommons.org/licenses/by/ $4.0 /)$.

\begin{abstract}
Copper plays an important role in alkyne coordination chemistry and transformations. This report describes the isolation and full characterization of a thermally stable, copper(I) acetylene complex using a highly fluorinated bis(pyrazolyl)borate ligand support. Details of the related copper(I) complex of $\mathrm{HC} \equiv \mathrm{CSiMe}_{3}$ are also reported. They are three-coordinate copper complexes featuring $\eta^{2}$-bound alkynes. Raman data show significant red-shifts in $\mathrm{C} \equiv \mathrm{C}$ stretch of $\left[\mathrm{H}_{2} \mathrm{~B}(3,5\right.$ $\left.\left.\left(\mathrm{CF}_{3}\right)_{2} \mathrm{Pz}\right)_{2}\right] \mathrm{Cu}(\mathrm{HC} \equiv \mathrm{CH})$ and $\left[\mathrm{H}_{2} \mathrm{~B}\left(3,5-\left(\mathrm{CF}_{3}\right)_{2} \mathrm{Pz}\right)_{2}\right] \mathrm{Cu}\left(\mathrm{HC} \equiv \mathrm{CSiMe}_{3}\right)$ relative to those of the corresponding alkynes. Computational analysis using DFT indicates that the $\mathrm{Cu}(\mathrm{I})$ alkyne interaction in these molecules is primarily of the electrostatic character. The $\pi$-backbonding is the larger component of the orbital contribution to the interaction. The dinuclear complexes such as $\mathrm{Cu}_{2}(\mu-[3,5-$ $\left.\left.\left(\mathrm{CF}_{3}\right)_{2} \mathrm{Pz}\right]\right)_{2}(\mathrm{HC} \equiv \mathrm{CH})_{2}$ display similar Cu-alkyne bonding features. The mononuclear $\left[\mathrm{H}_{2} \mathrm{~B}(3,5-\right.$ $\left.\left.\left(\mathrm{CF}_{3}\right)_{2} \mathrm{Pz}\right)_{2}\right] \mathrm{Cu}(\mathrm{NCMe})$ complex catalyzes [3+2] cycloadditions between tolyl azide and a variety of alkynes including acetylene. It is comparatively less effective than the related trinuclear copper catalyst $\left\{\mu-\left[3,5-\left(\mathrm{CF}_{3}\right)_{2} \mathrm{Pz}\right] \mathrm{Cu}\right\}_{3}$ involving bridging pyrazolates.
\end{abstract}

Keywords: copper; acetylene; alkyne; click chemistry; pyrazolyl borate

\section{Introduction}

Copper is an important metal in alkyne chemistry. It mediates a number of transformations of acetylene as well as larger alkynes including cycloaddition chemistry [1-5], cyclopropenation [6-8]. Terminal and Internal Alkyne Complexes and Azide-alkyne Cycloaddition Chemistry of Copper(I) Supported by a Fluorinated Bis(pyrazolyl)borate partial hydrogenation, $[9,10]$ hetero atom-hydrogen bond additions [11-16], $\mathrm{C}_{\mathrm{sp}}-\mathrm{H}$ bond functionalizations, and alkyne coupling processes [17-26]. Copper catalyzed azide-alkyne cycloaddition ( $\mathrm{CuAAC}$ ) is perhaps the most popular among the different reaction types due to its virtues of mild reaction conditions, high yields, and regioselectivity, with a major impact on organic and materials chemistry to chemical-biology applications [2,5,27-32]. Copper based materials are also useful for the separation of acetylene from $\mathrm{CO}_{2}$ and acetylene storage [33-37]. Copper alkyne or alkynide complexes [38] are believed to be key intermediates in many of these reactions. Copper alkynes are used as precursors for the copper deposition as well [39-41].

Over the past few years, we have been working on the coordination chemistry [42-47] and transformations [6,47-49] of alkynes involving copper. For example, we demonstrated that the trinuclear copper $(\mathrm{I})$ pyrazolate $\left\{\mu-\left[3,5-\left(\mathrm{CF}_{3}\right)_{2} \mathrm{Pz}\right] \mathrm{Cu}\right\}_{3}[50]$ is an effective catalyst for facile azide-alkyne cycloaddition leading to 1,2,3-triazoles, alkyne C(sp)-H bond carboxylation with $\mathrm{CO}_{2}$, and $\mathrm{S}-\mathrm{H}$ addition to alkyne moiety [47]. Some of the alkyne complexes of copper pyrazolates show interesting luminescence [46]. We also discovered 
that the mononuclear, bis(pyrazolyl)borate $\left[\mathrm{H}_{2} \mathrm{~B}\left(3,5-\left(\mathrm{CF}_{3}\right)_{2} \mathrm{Pz}\right)_{2}\right] \mathrm{Cu}(\mathrm{NCMe})(\mathbf{1}, \mathrm{Pz}=$ pyrazolyl; Figure 1) is an excellent mediator of cyclopropenation chemistry of alkynes with ethyl diazoacetate.[6]
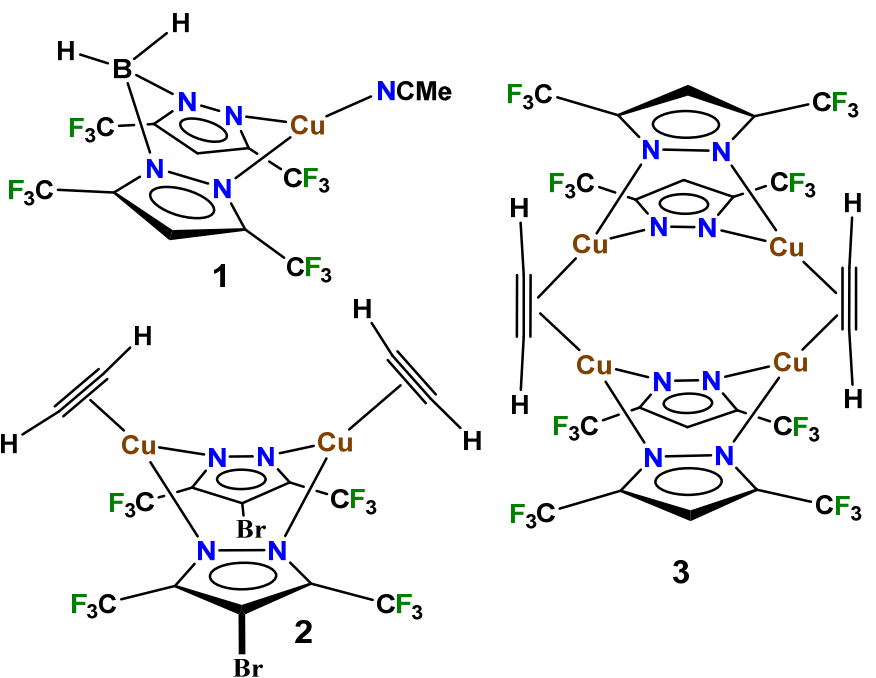

Figure 1. $\left[\mathrm{H}_{2} \mathrm{~B}\left(3,5-\left(\mathrm{CF}_{3}\right)_{2} \mathrm{Pz}\right)_{2}\right] \mathrm{Cu}(\mathrm{NCMe})(\mathbf{1})$ and a selected group of structurally characterized copper complexes of acetylene, $\mathrm{Cu}_{2}\left(\mu-\left[4-\mathrm{Br}-3,5-\left(\mathrm{CF}_{3}\right)_{2} \mathrm{Pz}\right]\right)_{2}(\mathrm{HC} \equiv \mathrm{CH})_{2}(2)$ and $\mathrm{Cu}_{4}\left(\mu-\left[3,5-\left(\mathrm{CF}_{3}\right)_{2} \mathrm{Pz}\right]\right)_{4}(\mu-$ $\mathrm{HC} \equiv \mathrm{CH})_{2}(3)$.

In this work, we describe the use of $\left[\mathrm{H}_{2} \mathrm{~B}\left(3,5-\left(\mathrm{CF}_{3}\right)_{2} \mathrm{Pz}\right)_{2}\right] \mathrm{Cu}(\mathrm{NCMe})$ as a catalyst in azide-alkyne cycloaddition chemistry between $p$-tolylazide and several alkynes including acetylene and trimethylsilylacetylene. We also describe the isolation of an acetylene complex as well as larger alkyne complexes involving the copper bis(pyrazolyl)borate moiety $\left[\mathrm{H}_{2} \mathrm{~B}\left(3,5-\left(\mathrm{CF}_{3}\right)_{2} \mathrm{Pz}\right)_{2}\right] \mathrm{Cu}$. Such compounds are of current interest $[38,51,52]$ and allow a comparison of mono-nuclear copper bis(pyrazolyl)borates to dinuclear copper(I) pyrazolates (e.g., $\left[\mathrm{H}_{2} \mathrm{~B}\left(3,5-\left(\mathrm{CF}_{3}\right)_{2} \mathrm{Pz}\right)_{2}\right] \mathrm{Cu}(\mathrm{HC} \equiv \mathrm{CH})(4)$ and $\mathrm{Cu}_{2}\left(\mu-\left[4-\mathrm{Br}-3,5-\left(\mathrm{CF}_{3}\right)_{2} \mathrm{Pz}\right]\right)_{2}(\mathrm{HC} \equiv \mathrm{CH})_{2}$ (2)). It is also noteworthy that despite the long history of copper(I)-acetylene chemistry $[53,54]$, copper(I) acetylene complexes with detailed structural and spectroscopic data are surprisingly scarce. For example, apart from the dinuclear and tetranuclear copper complexes 2 and $\mathrm{Cu}_{4}\left(\mu-\left[3,5-\left(\mathrm{CF}_{3}\right)_{2} \mathrm{Pz}\right]\right)_{4}(\mu-\mathrm{HC} \equiv \mathrm{CH})_{2}$ (3) reported by us recently [47], structurally authenticated copper- $\mathrm{C}_{2} \mathrm{H}_{2}$ complexes are limited to $\left[\mathrm{Cu}\left\{\mathrm{NH}(\mathrm{Py})_{2}\right\}(\mathrm{HC} \equiv \mathrm{CH})\right] \mathrm{BF}_{4}$ and $[\mathrm{Cu}$ (phen) $(\mathrm{HC} \equiv \mathrm{CH})] \mathrm{ClO}_{4}$ with $\mathrm{Cu}\left(\eta^{2}-\mathrm{HC} \equiv \mathrm{CH}\right)$ moieties [55-57] and polymeric or octanuclear, chloride bridged copper $(\mathrm{I})$ adducts containing $\mu_{2}-\eta^{2}, \eta^{2}-(\mathrm{HC} \equiv \mathrm{CH})$ moieties [58-60].

\section{Results and Discussion}

The bis(pyrazolyl)borate copper(I) complex $\left[\mathrm{H}_{2} \mathrm{~B}\left(3,5-\left(\mathrm{CF}_{3}\right)_{2} \mathrm{Pz}\right)_{2}\right] \mathrm{Cu}(\mathrm{NCMe})[42]$ reacts with purified acetylene $(\sim 1 \mathrm{~atm})[61,62]$ in $\mathrm{CH}_{2} \mathrm{Cl}_{2}$, affording $\left[\mathrm{H}_{2} \mathrm{~B}\left(3,5-\left(\mathrm{CF}_{3}\right)_{2} \mathrm{Pz}\right)_{2}\right] \mathrm{Cu}(\mathrm{HC} \equiv \mathrm{CH})$ (4) as a white solid in $>90 \%$ yield (Scheme 1 ), which is quite amenable to detailed spectroscopic and structural studies. The room temperature ${ }^{1} \mathrm{H}$ NMR spectrum of 4 in $\mathrm{CDCl}_{3}$ displayed the acetylenic proton resonances at $\delta 4.70 \mathrm{ppm}$. That is a significant downfield shift relative to the corresponding signal of the free acetylene $(\delta 2.01 \mathrm{ppm})$ [63]. The ${ }^{13} \mathrm{C}$ resonance of the acetylenic carbons appears at $\delta 80.2 \mathrm{ppm}$, which is a downfield shift of $7.0 \mathrm{ppm}$ relative to that of the free acetylene $(\delta 73.2 \mathrm{ppm})$ [63]. The $\bar{v}_{\mathrm{C} \equiv \mathrm{C}}$ band of solid 4 in the Raman spectrum was observed at $1819 \mathrm{~cm}^{-1}$, representing a $155 \mathrm{~cm}^{-1}$ red shift relative to the corresponding stretching frequency of the free $\mathrm{HC} \equiv \mathrm{CH}\left(1974 \mathrm{~cm}^{-1}\right)$ [64]. This red shift is not as high as that observed for $\mathrm{Cu}_{4}\left(\mu-\left[3,5-\left(\mathrm{CF}_{3}\right)_{2} \mathrm{Pz}\right]\right)_{4}(\mu-\mathrm{HC} \equiv \mathrm{CH})_{2}$ (3 with $\bar{v}_{\mathrm{C} \equiv \mathrm{C}}$ of $1638 \mathrm{~cm}^{-1}$ ) containing a $\mu_{2}-\eta^{2}, \eta^{2}-(\mathrm{HC} \equiv \mathrm{CH}$ ) (which is a formally $4 \mathrm{e}-$ donor, bridging acetylene). Table 1 shows available, albeit limited, ${ }^{1} \mathrm{H}$ and ${ }^{13} \mathrm{C}$ NMR data and $\mathrm{C} \equiv \mathrm{C}$ stretch of structurally characterized copper complexes featuring a formally 2e-donor $\eta^{2}-(\mathrm{HC} \equiv \mathrm{CH})$. $\left[\mathrm{H}_{2} \mathrm{~B}\left(3,5-\left(\mathrm{CF}_{3}\right)_{2} \mathrm{Pz}\right)_{2}\right] \mathrm{Cu}(\mathrm{HC} \equiv \mathrm{CH})(4)$ shows the smallest 
downfield shift of the acetylenic NMR signal, and red-shift of $C \equiv C$ stretching frequency relative to that of the free $\mathrm{HC} \equiv \mathrm{CH}$ among these (although the differences are minor), suggesting relatively weaker $\sigma / \pi$-interaction between the copper(I) and acetylene ligand in terms of the Dewar-Chatt-Duncanson picture [65,66]. A rare, well-authenticated silver(I)acetylene complex, $\left[\mathrm{HB}\left(3,5-\left(\mathrm{CF}_{3}\right)_{2} \mathrm{Pz}\right)_{3}\right] \mathrm{Ag}(\mathrm{HC} \equiv \mathrm{CH})$ is also available for a comparison (although it has a tris(pyrazolyl)borate (not bis(pyrazolyl)borate) ligand support) [67]. It is a system that features relatively low $\mathrm{M} \rightarrow$ alkyne backbonding. The acetylenic ${ }^{1} \mathrm{H}$ signal of this silver(I) complex has been observed at $\delta 3.48 \mathrm{ppm}$, which is an even smaller downfield shift from the free acetylene resonance $(\delta 2.01 \mathrm{ppm})$, compared to that observed for $\left[\mathrm{H}_{2} \mathrm{~B}\left(3,5-\left(\mathrm{CF}_{3}\right)_{2} \mathrm{Pz}\right)_{2}\right] \mathrm{Cu}(\mathrm{HC} \equiv \mathrm{CH})(4)$. Interestingly, alkyne resonance of $[\mathrm{HB}(3,5-$ $\left.\left.\left(\mathrm{CF}_{3}\right)_{2} \mathrm{Pz}\right)_{3}\right] \mathrm{Ag}(\mathrm{HC} \equiv \mathrm{CH})$ in ${ }^{13} \mathrm{C}$ NMR appears at $\delta 66.3 \mathrm{ppm}$.

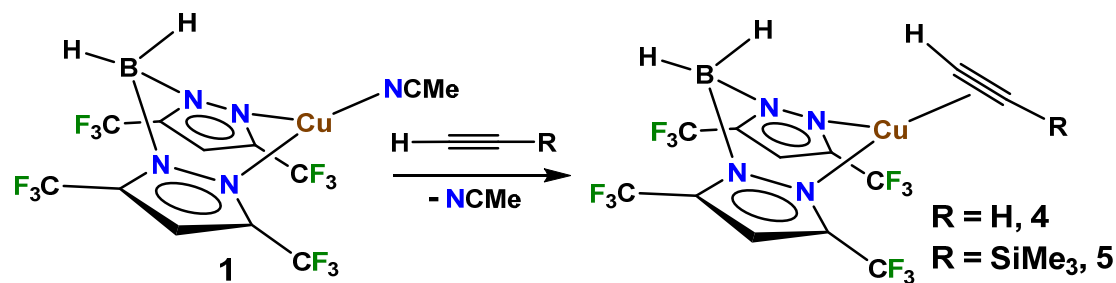

Scheme 1. Synthesis of $\left[\mathrm{H}_{2} \mathrm{~B}\left(3,5-\left(\mathrm{CF}_{3}\right)_{2} \mathrm{Pz}\right)_{2}\right] \mathrm{Cu}(\mathrm{HC} \equiv \mathrm{CH})(4)$ and $\left[\mathrm{H}_{2} \mathrm{~B}\left(3,5-\left(\mathrm{CF}_{3}\right)_{2} \mathrm{Pz}\right)_{2}\right] \mathrm{Cu}\left(\mathrm{HC} \equiv \mathrm{CSiMe}_{3}\right)$ (5) from $\left[\mathrm{H}_{2} \mathrm{~B}\left(3,5-\left(\mathrm{CF}_{3}\right)_{2} \mathrm{Pz}\right)_{2}\right] \mathrm{Cu}(\mathrm{NCMe})(\mathbf{1})$ and the corresponding alkyne.

Overall, acetylenic ${ }^{1} \mathrm{H}$ and ${ }^{13} \mathrm{C}$ resonance of d-block metal complexes bearing 2e-donor, $\eta^{2}$-acetylene ligands has been observed (keeping in mind that $\eta^{2}$-acetylene can also serve as a formally 4e-donor moiety) at quite a wide chemical shift range [68]. For example, NMR spectra of $\mathrm{Ru}(\mathrm{II})$ complex [Cp* $\left.\mathrm{Ru}(\mathrm{HC} \equiv \mathrm{CH})\left(\mathrm{PEt}_{3}\right)_{2}\right]\left[\mathrm{BPh}_{4}\right]$ [69] and $\mathrm{Ni}(0)$ complex $\left(\mathrm{Ph}_{3} \mathrm{P}\right)_{2} \mathrm{Ni}(\mathrm{HC} \equiv \mathrm{CH})[70]$ display their signals for the metal bound $\mathrm{C}_{2} \mathrm{H}_{2}$ in ${ }^{1} \mathrm{H}$ and ${ }^{13} \mathrm{C}$ at $\delta$ $4.38,66.14 \mathrm{ppm}$ and $\delta 6.41,122 \mathrm{ppm}$, respectively. The latter nickel complex is expected to display more pronounced $\mathrm{M} \rightarrow$ alkyne backbonding than in 4 . For comparison, protons of the bridging acetylene group of $\mathrm{Cu}_{4}\left(\mu-\left[3,5-\left(\mathrm{CF}_{3}\right)_{2} \mathrm{Pz}\right]\right)_{4}(\mu-\mathrm{HC} \equiv \mathrm{CH})_{2}(3)$ have been observed at $\delta 6.16 \mathrm{ppm}[47]$.

Table 1. Selected bond distances $(\AA)$ and angles $\left(^{\circ}\right)$ for $\left[\mathrm{H}_{2} \mathrm{~B}\left(3,5-\left(\mathrm{CF}_{3}\right)_{2} \mathrm{Pz}\right)_{2}\right] \mathrm{Cu}(\mathrm{HC} \equiv \mathrm{CH})(4), \mathrm{Cu}_{2}(\mu-$ $\left.\left[4-\mathrm{Br}-3,5-\left(\mathrm{CF}_{3}\right)_{2} \mathrm{Pz}\right]\right)_{2}(\mathrm{HC} \equiv \mathrm{CH})_{2}(2),\left[\mathrm{Cu}\left\{\mathrm{NH}(\mathrm{Py})_{2}\right\}(\mathrm{HC} \equiv \mathrm{CH})\right] \mathrm{BF}{ }_{4}$ and $[\mathrm{Cu}(\mathrm{phen}) .(\mathrm{HC} \equiv \mathrm{CH})] \mathrm{ClO}_{4}$. Specific bond distances and angles of 4 are presented in $\mathrm{CIF}$ and Supporting Information section. Data collection temperatures are in Kelvin. Free acetylene $\mathrm{C} \equiv \mathrm{C}$ distance, $\mathrm{C} \equiv \mathrm{C}$ stretching frequency, ${ }^{1} \mathrm{H}$ and ${ }^{13} \mathrm{C}$ chemical shifts are 1.2033(2) $\AA$ (gas phase) and 1.193(6) $\AA$ (neutron diffraction-less accurate) [71,72], $1974 \mathrm{~cm}^{-1}, 2.01 \mathrm{ppm}$, and $73.2 \mathrm{ppm}$ [63], respectively.

\begin{tabular}{|c|c|c|c|c|}
\hline $\begin{array}{l}\text { Complex } \backslash \\
\text { Parameter }\end{array}$ & 4 & 2 & $\begin{array}{c}{\left[\mathrm{Cu}\left\{\mathrm{NH}(\mathrm{Py})_{2}\right\}\right.} \\
(\mathrm{HC} \equiv \mathrm{CH})]_{B F}\end{array}$ & $\begin{array}{c}{[\mathrm{Cu}(\text { phen })} \\
(\mathrm{HC} \equiv \mathrm{CH})] \mathrm{ClO}_{4}\end{array}$ \\
\hline Temp. & 100 & 100 & 173 & $283-303$ \\
\hline \multirow{2}{*}{$\mathrm{Cu}-\mathrm{C}$} & $1.972(3)$ & $1.966(3)$ & $1.971(3)$ & $1.930(5)$ \\
\hline & $1.973(3)$ & $1.974(3)$ & $1.971(3)$ & $1.961(5)$ \\
\hline $\mathrm{C} \equiv \mathrm{C}$ & $1.225(5)$ & $1.227(4)$ & $1.188(11)$ & $1.190(7)$ \\
\hline \multirow{2}{*}{$\mathrm{Cu}-\mathrm{N}$} & $1.981(3)$ & $1.9697(18)$ & $1.968(3)$ & $1.979(4)$ \\
\hline & $1.981(3)$ & $1.9742(18)$ & $1.968(3)$ & $1.978(4)$ \\
\hline $\mathrm{C}-\mathrm{Cu}-\mathrm{C}$ & $36.17(14)$ & $36.29(11)$ & $35.1(3)$ & $35.6(2)$ \\
\hline $\mathrm{N}-\mathrm{Cu}-\mathrm{N}$ & $96.63(10)$ & $98.94(8)$ & $96.8(2)$ & $84.9(2)$ \\
\hline $\bar{v}(\mathrm{C} \equiv \mathrm{C})$ & 1819 & 1811 & 1795 & 1800 \\
\hline${ }^{1} \mathrm{H}$ & 4.40 & 4.75 & 5.21 & - \\
\hline${ }^{13} \mathrm{C}$ & 80.2 & - & - & - \\
\hline ref & This work & [47] & [57] & [56] \\
\hline
\end{tabular}


The X-ray crystal structure of $\left[\mathrm{H}_{2} \mathrm{~B}\left(3,5-\left(\mathrm{CF}_{3}\right)_{2} \mathrm{Pz}\right)_{2}\right] \mathrm{Cu}(\mathrm{HC} \equiv \mathrm{CH})(4)$ is illustrated in Figure 2. It is a three coordinate, trigonal planar copper-acetylene complex. The acetylene ligand is oriented parallel to the $\mathrm{NCuN}$ plane so as to maximize back-bonding interactions [73]. Selected bond distances and angles of 4 and copper complexes featuring 2e-donor, $\eta^{2}$-acetylene ligand in the literature are given in Table 1 . The key parameters involving the $\mathrm{CuC}_{2}$ core are remarkably similar between these molecules. This suggests that cationic copper species $\left[\mathrm{Cu}\left\{\mathrm{NH}(\mathrm{Py})_{2}\right\}(\mathrm{HC} \equiv \mathrm{CH})\right] \mathrm{BF}_{4}$ and $[\mathrm{Cu}($ phen $)(\mathrm{HC} \equiv \mathrm{CH})] \mathrm{ClO}_{4}$ featuring relatively electron-rich supporting ligands and neutral copper complexes $\mathbf{4}$ and 2 involving weakly donating fluorinated ligands have similar effects on the $\mathrm{Cu}-\mathrm{C}_{2} \mathrm{H}_{2}$ alkyne moiety, or produce effects that are not large enough to be parsed out by routine $X$-ray crystallography. They both show slightly elongated $\mathrm{C} \equiv \mathrm{C}$ bonds relative to the free acetylene (1.181(7) A) [74], but these changes are overshadowed by the somewhat high esd associated with bond distance measurements.

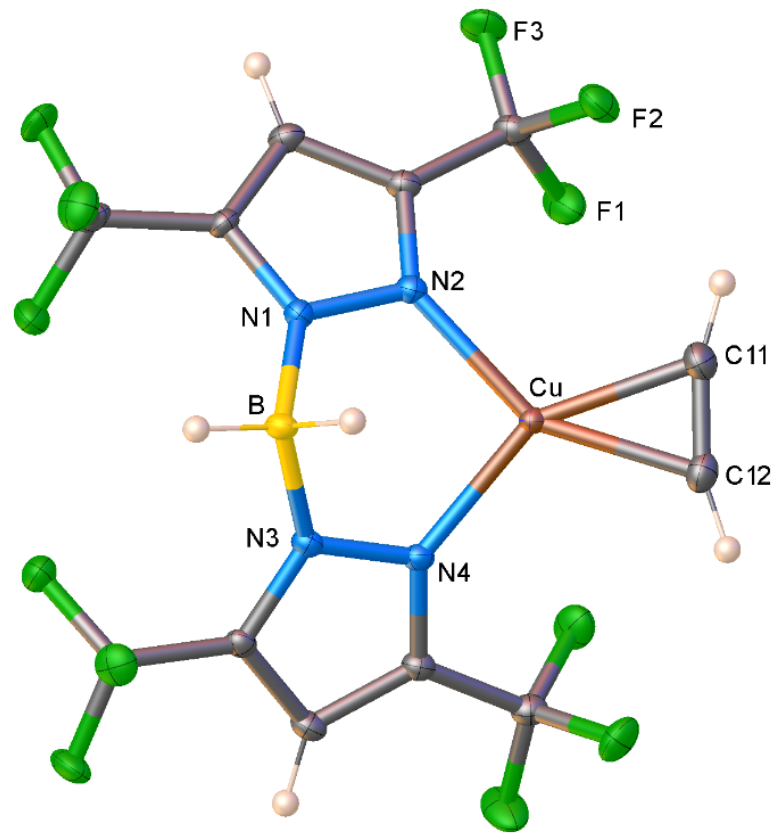

Figure 2. Molecular structure of $\left[\mathrm{H}_{2} \mathrm{~B}\left(3,5-\left(\mathrm{CF}_{3}\right)_{2} \mathrm{Pz}\right)_{2}\right] \mathrm{Cu}(\mathrm{HC} \equiv \mathrm{CH})(4)$; ORTEP view with $50 \%$ probability ellipsoids are shown. Selected bond distances $(\AA)$ and angles $\left(^{\circ}\right)$ : Cu-N2 1.981(3), Cu-N4 1.981(3), Cu-C11 1.972(3), Cu-C12 1.973(3), C11-C12 1.225(5), B-N1 1.570(4), B-N3 1.569(4), CuB B 3.046, C11-Cu-C12 36.17(14), N2-Cu-N4 96.63(10), N4-Cu-C12 113.19(13), N2-Cu-C11 114.01(13), N1-B-N3 107.6(2).

In addition to acetylene, we also tested the use of $\mathrm{HC} \equiv \mathrm{CSiMe}_{3}$ as a substrate in CuACC chemistry. Considering that structurally authenticated metal complexes of $\eta^{2}$ $\mathrm{HC} \equiv \mathrm{CSiMe}_{3}$ are rare (a search of Cambridge Structural Database [75] disclosed only three such examples involving transition metal ions) [76-78] and unknown for copper to our knowledge [75], we also synthesized $\left[\mathrm{H}_{2} \mathrm{~B}\left(3,5-\left(\mathrm{CF}_{3}\right)_{2} \mathrm{Pz}\right)_{2}\right] \mathrm{Cu}\left(\mathrm{HC} \equiv \mathrm{CSiMe}_{3}\right)(5)$ for a detailed study. Treatment of $\left[\mathrm{H}_{2} \mathrm{~B}\left(3,5-\left(\mathrm{CF}_{3}\right)_{2} \mathrm{Pz}\right)_{2}\right] \mathrm{Cu}(\mathrm{NCMe})$ with $\mathrm{HC} \equiv \mathrm{CSiMe}_{3}$ in $\mathrm{CH}_{2} \mathrm{Cl}_{2}$ led to 5 in $91 \%$ yield (Scheme 1). It is a white solid and was characterized by NMR and Raman spectroscopy and X-ray crystallography. The $\bar{v}_{\mathrm{C} \equiv C}$ band of solid $\mathbf{5}$ in the Raman spectrum was observed at $1870 \mathrm{~cm}^{-1}$, which is a $237 \mathrm{~cm}^{-1}$ red shift relative to the corresponding stretching frequency of the free $\mathrm{HC} \equiv \mathrm{CSiMe}_{3}\left(2107 \mathrm{~cm}^{-1}\right)$. This $\bar{v}(\mathrm{C} \equiv \mathrm{C})$ is similar to that reported for $\left[\mathrm{HC}\left\{\mathrm{C}\left(\mathrm{CF}_{3}\right) \mathrm{CO}_{2}\right] \mathrm{Cu}\left(\mathrm{HC} \equiv \mathrm{CSiMe}_{3}\right)\right.$ [41]. This suggests the presence of an $\eta^{2}-\mathrm{HC} \equiv \mathrm{CSiMe}_{3}$ bound alkyne moiety on copper(I) $[46,51]$.

X-ray crystal structure of $\left[\mathrm{H}_{2} \mathrm{~B}\left(3,5-\left(\mathrm{CF}_{3}\right)_{2} \mathrm{Pz}\right)_{2}\right] \mathrm{Cu}\left(\mathrm{HC} \equiv \mathrm{CSiMe}_{3}\right)$ (5) is depicted in Figure 3. It is a monomeric, trigonal planar copper complex with an $\eta^{2}-\mathrm{HC} \equiv \mathrm{CSiMe}_{3}$ bound alkyne moiety. The $\mathrm{HC} \equiv \mathrm{CSiMe}_{3}$ is bonded slightly asymmetrically as evident from the marginally longer $\mathrm{Cu}-\mathrm{C} 12$, which is a carbon atom with the larger, silyl group. 
The alkyne group shows a significant deviation from the ideal $180^{\circ}$ as evident from $\mathrm{C} \equiv \mathrm{C}-\mathrm{Si}$ angle, $160.64(11)^{\circ}$. This is about $19^{\circ}$ bending back of the alkyne group due to the metal ion coordination. As noted above, there are no structural data on related copper $\eta^{2}-\mathrm{HC} \equiv \mathrm{CSiMe}_{3}$ complexes for comparisons. The $\mathrm{Cp}_{2} \mathrm{Nb}(\mathrm{H})(\mathrm{HC} \equiv \mathrm{CSiMe})_{3}$ [76] and $(\mathrm{NMe}-\mathrm{Paa}) \mathrm{W}(\mathrm{CO}) \mathrm{F}\left(\mathrm{HC} \equiv \mathrm{CSiMe}_{3}\right)$ (based on a $\kappa^{3}-\left[\mathrm{C}, \mathrm{N}, \mathrm{N}^{\prime}\right]$ chelator NMe-Paa $=2-(2-$ dimethylaminoethyl)methylaminomethylphenyl) [78] complexes are known and display significantly smaller C $\equiv \mathrm{C}$-Si angles of $141.7(5)^{\circ}$ and $138.1(1)^{\circ}$ (or much larger deviation from linearity), which points to stronger metal-alkyne $\sigma / \pi$-bonding in these $W($ II) and $\mathrm{Nb}$ (III) complexes, in terms of the Dewar-Chatt-Duncanson model $[65,66]$.

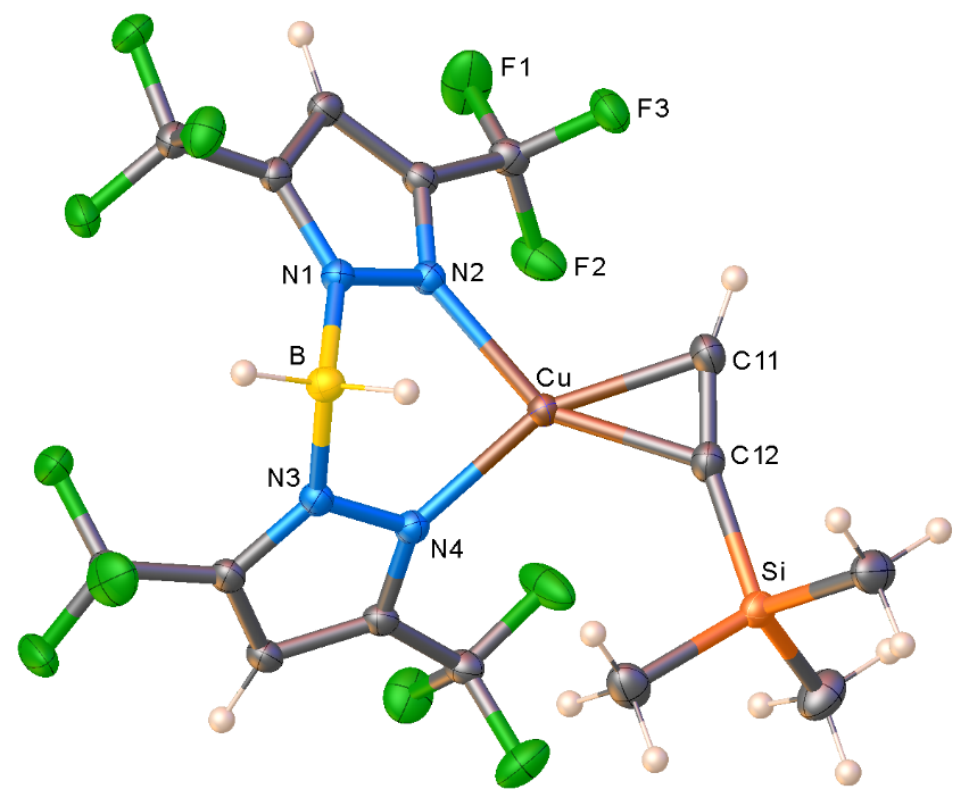

Figure 3. Molecular structure of $\left[\mathrm{H}_{2} \mathrm{~B}\left(3,5-\left(\mathrm{CF}_{3}\right)_{2} \mathrm{Pz}\right)_{2}\right] \mathrm{Cu}\left(\mathrm{HC} \equiv \mathrm{CSiMe}_{3}\right)$ (5); ORTEP view with $50 \%$ probability ellipsoids are shown. Selected bond distances $(\AA)$ and angles $\left(^{\circ}\right)$ : Cu-N2 1.9857(9), Cu-N4 1.9845(9), Cu-C11 1.9600(12), Cu-C12 1.9957(11), C11-C12 1.2343(17), B-N1 1.5778(15), B-N3 1.5737(16), C12-Si 1.8713(12), Cu‥B 2.964, C11-Cu-C12 36.35(5), N2-Cu-N4 90.59(4), N4-Cu-C12 120.05(4), N2-Cu-C11 112.92(5), N1-B-N3 106.41(9), C11-C12-Si 160.64(11).

Compounds $\left[\mathrm{H}_{2} \mathrm{~B}\left(3,5-\left(\mathrm{CF}_{3}\right)_{2} \mathrm{Pz}\right)_{2}\right] \mathrm{Cu}(\mathrm{HC} \equiv \mathrm{CH})(4)$ and $\mathrm{Cu}_{2}\left(\mu-\left[4-\mathrm{Br}-3,5-\left(\mathrm{CF}_{3}\right)_{2} \mathrm{Pz}\right]\right)_{2}(\mathrm{HC} \equiv \mathrm{CH})_{2}$ (2) (note: non-brominated, $\mathrm{Cu}_{2}\left(\mu-\left[3,5-\left(\mathrm{CF}_{3}\right)_{2} \mathrm{Pz}\right]\right)_{2}(\mathrm{HC} \equiv \mathrm{CH})_{2}$ analog has been observed but not isolated) allow us to compare the effects of replacing a $\left[\mathrm{H}_{2} \mathrm{~B}\right]^{+}$with a $[(\text {alkyne }) \mathrm{Cu}]^{+}$ moiety in these systems. Although structural features of $\mathrm{N}_{2} \mathrm{CuC}_{2}$ core are very comparable (Table 1), ${ }^{1} \mathrm{H}$ and Raman spectroscopic data of the alkyne group suggest that the copper site in the mononuclear 4 is slightly more Lewis acidic than that of dinuclear 5, despite having a 4-bromo pyrazolate in the latter. Table S1 (Supplementary Materials) in supporting information shows two additional sets of molecules, more closely related to each other; $\left[\mathrm{H}_{2} \mathrm{~B}(3,5-\right.$ $\left.\left.\left(\mathrm{CF}_{3}\right)_{2} \mathrm{Pz}\right)_{2}\right] \mathrm{Cu}(\mathrm{EtC} \equiv \mathrm{CEt})(6)[6]$ and $\mathrm{Cu}_{2}\left(\mu-\left[3,5-\left(\mathrm{CF}_{3}\right)_{2} \mathrm{Pz}\right]\right)_{2}(\mathrm{EtC} \equiv \mathrm{CEt})_{2}(7)[46]$ as well as $\left[\mathrm{H}_{2} \mathrm{~B}\left(3,5-\left(\mathrm{CF}_{3}\right)_{2} \mathrm{Pz}\right)_{2}\right] \mathrm{Cu}(\mathrm{HC} \equiv \mathrm{CPh})(8)[42]$ and $\mathrm{Cu}_{2}\left(\mu-\left[3,5-\left(\mathrm{CF}_{3}\right)_{2} \mathrm{Pz}\right]\right)_{2}(\mathrm{HC} \equiv \mathrm{CPh})_{2}(9)$ [47]. To facilitate this analysis, the $X$-ray crystal structure of $\left[\mathrm{H}_{2} \mathrm{~B}\left(3,5-\left(\mathrm{CF}_{3}\right)_{2} \mathrm{Pz}\right)_{2}\right] \mathrm{Cu}(\mathrm{EtC} \equiv \mathrm{CEt})$ was also investigated and the details are included in the Supporting Information [6]. A comparison of mononuclear bis(pyrazolyl)borate systems to the corresponding dinuclear pyrazolate systems show very similar metrical parameters involving the $\mathrm{N}_{2} \mathrm{CuC}$ cores, except for N-Cu-N angles, which are smaller for the bis(pyrazolyl)borate copper complexes. Closer analysis indicates that this is not because of noticeably longer $\mathrm{Cu}-\mathrm{N}$ distances in bis(pyrazolyl)borate copper systems but due to their more folded $\mathrm{CuN}_{4} \mathrm{~B}$ cores (compared to the flatter $\mathrm{CuN}_{4} \mathrm{C}$ rings in the related dinuclear pyrazolates). This is evident from the separation of the pyrazolyl ring carbons at 4-positions (e.g., Pz-C4 $\cdots$ Pz-C4 distance of 
$\left[\mathrm{H}_{2} \mathrm{~B}\left(3,5-\left(\mathrm{CF}_{3}\right)_{2} \mathrm{Pz}\right)_{2}\right] \mathrm{Cu}(\mathrm{EtC} \equiv \mathrm{CEt})(6)$ and $\mathrm{Cu}_{2}\left(\mu-\left[3,5-\left(\mathrm{CF}_{3}\right)_{2} \mathrm{Pz}\right]\right)_{2}(\mathrm{EtC} \equiv \mathrm{CEt})_{2}(7)$ is 6.18 and $6.38 \AA$ ).

Further analysis of the alkyne-copper(I) interaction is performed using density functional calculations (Table 2) to understand the variations between the mononuclear and dinuclear species as well as the copper and different alkynes. The overall interaction energy $\left(\Delta E_{\text {int }}\right)$ between the alkyne and copper(I) center for mononuclear species $\left[\mathrm{H}_{2} \mathrm{~B}\left(3,5-\left(\mathrm{CF}_{3}\right)_{2} \mathrm{Pz}\right)_{2}\right]$ $\mathrm{Cu}(\mathrm{HC} \equiv \mathrm{CH})(4),\left[\mathrm{H}_{2} \mathrm{~B}\left(3,5-\left(\mathrm{CF}_{3}\right)_{2} \mathrm{Pz}\right)_{2}\right] \mathrm{Cu}(\mathrm{EtC} \equiv \mathrm{CEt})(6)$, and $\left[\mathrm{H}_{2} \mathrm{~B}\left(3,5-\left(\mathrm{CF}_{3}\right)_{2} \mathrm{Pz}\right)_{2}\right] \mathrm{Cu}(\mathrm{PhC} \equiv \mathrm{CH})$ (8) is $-46.8,-51.5$, and $-49.4 \mathrm{kcal} \cdot \mathrm{mol}^{-1}$, respectively, which is further dissected in different contributions within the Ziegler-Rauk energy decomposition analysis (EDA) [79,80]. In this framework, the interaction energy $\left(\Delta \mathrm{E}_{\text {int }}\right)$ exhibits a larger electrostatic character $\left(\Delta \mathrm{E}_{\text {elstat }}\right)$ of about $\sim 60 \%$ of the stabilizing terms, whereas the orbital contribution to the interaction is about $\sim 35 \%\left(\Delta \mathrm{E}_{\text {orb }}\right)$, with the remaining $\sim 5 \%$ attributable to dispersion-type contributions $\left(\Delta \mathrm{E}_{\text {disp }}\right)$. The $\Delta \mathrm{E}_{\text {orb }}$ involves both $\pi$-backdonation and $\sigma$-donation, which contributes $57.2 \%$ and $26.3 \%$ to the bonding stabilization of 4 . The $\pi$-backbonding contribution in $\mathrm{EtC} \equiv \mathrm{CEt}$ and $\mathrm{PhC} \equiv \mathrm{CH}$ counterparts is similar to that of 4 (Figure 4). For the dinuclear species, $\mathrm{Cu}_{2}\left(\mu-\left[3,5-\left(\mathrm{CF}_{3}\right)_{2} \mathrm{Pz}\right]\right)_{2}(\mathrm{HC} \equiv \mathrm{CH})_{2}(\mathbf{1 0}), \mathrm{Cu}_{2}\left(\mu-\left[3,5-\left(\mathrm{CF}_{3}\right)_{2} \mathrm{Pz}\right]\right)_{2}(\mathrm{EtC} \equiv \mathrm{CEt})_{2}(7)$, and $\mathrm{Cu}_{2}\left(\mu-\left[3,5-\left(\mathrm{CF}_{3}\right)_{2} \mathrm{Pz}\right]\right)_{2}(\mathrm{HC} \equiv \mathrm{CPh})_{2}(9)$, the $\mathrm{Cu}$-alkyne interaction energy $\left(\Delta \mathrm{E}_{\text {int }}\right)$ amounts to $-43.8,-49.4$ and $-47.8 \mathrm{kcal} \cdot \mathrm{mol}^{-1}$, respectively. These values are slightly lower than the somewhat related mononuclear, bis(pyrazolyl)borate species. They, however, involve similar bonding characteristics. The structurally characterized, brominated species $\mathrm{Cu}_{2}(\mu-[4-\mathrm{Br}-$ $\left.\left.3,5-\left(\mathrm{CF}_{3}\right)_{2} \mathrm{Pz}\right]\right)_{2}(\mathrm{HC} \equiv \mathrm{CH})_{2}$ (2) with an Cu-alkyne interaction energy of $-42.9 \mathrm{kcal} \cdot \mathrm{mol}^{-1}$, shows a slight destabilization in comparison to $\mathrm{Cu}_{2}\left(\mu-\left[3,5-\left(\mathrm{CF}_{3}\right)_{2} \mathrm{Pz}\right]\right)_{2}(\mathrm{HC} \equiv \mathrm{CH})_{2}(\mathbf{1 0})$.

a)
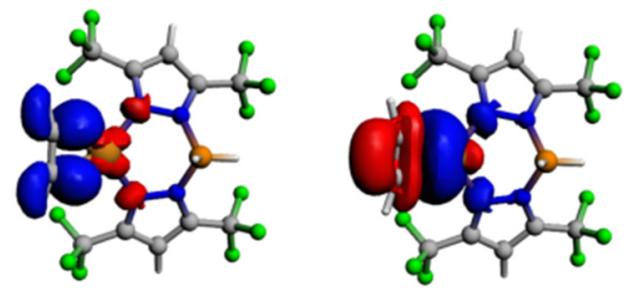

b)
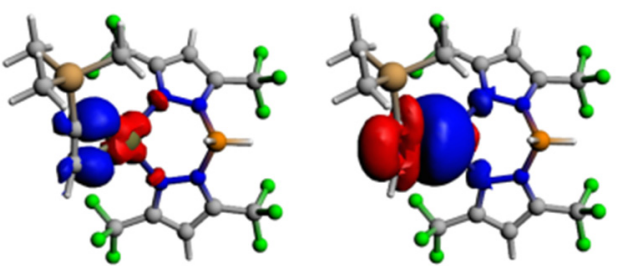

c)
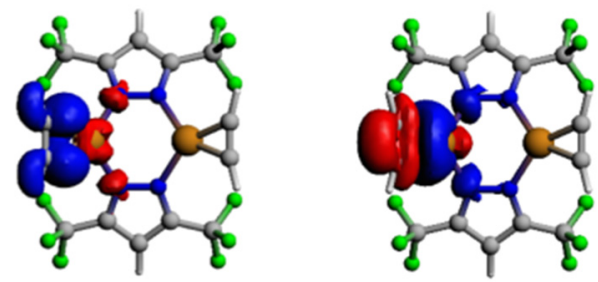

Figure 4. Representative deformation densities accounting for the $\pi$-backbonding (left) and $\sigma$ donation (right) contribution to the bonding scheme in the formation of alkyl copper complexes (from top to bottom) for (a) $\left[\mathrm{H}_{2} \mathrm{~B}\left(3,5-\left(\mathrm{CF}_{3}\right)_{2} \mathrm{Pz}\right)_{2}\right] \mathrm{Cu}(\mathrm{HC} \equiv \mathrm{CH})(\mathbf{4}),(\mathbf{b})\left[\mathrm{H}_{2} \mathrm{~B}\left(3,5-\left(\mathrm{CF}_{3}\right)_{2} \mathrm{Pz}\right)_{2}\right] \mathrm{Cu}\left(\mathrm{HC} \equiv \mathrm{CSiMe}_{3}\right)$ (5) and (c) the dinuclear $\mathrm{Cu}_{2}\left(\mu-\left[3,5-\left(\mathrm{CF}_{3}\right)_{2} \mathrm{Pz}\right]\right)_{2}(\mathrm{HC} \equiv \mathrm{CH})_{2}(\mathbf{1 0})$. Charge flow from red to blue.

We also probed the effect of different substituents on the alkyne moieties by including a phenyl and silyl group $-\mathrm{SiMe}_{3}$ (Table 2). In $\left[\mathrm{H}_{2} \mathrm{~B}\left(3,5-\left(\mathrm{CF}_{3}\right)_{2} \mathrm{Pz}\right)_{2}\right] \mathrm{Cu}(\mathrm{PhC} \equiv \mathrm{CH})(8)$ and $\left[\mathrm{H}_{2} \mathrm{~B}\left(3,5-\left(\mathrm{CF}_{3}\right)_{2} \mathrm{Pz}\right)_{2}\right] \mathrm{Cu}\left(\mathrm{HC} \equiv \mathrm{CSiMe}_{3}\right)(5)$, the Cu-alkyne stabilization increases slightly due to a small increase of the electrostatic character in comparison to the $\mathrm{HC} \equiv \mathrm{CH}$ counterpart (4). Moreover, if the silicon atom in the silyl derivative is replaced by a carbon atom, that is $-\mathrm{CMe}_{3}$, the stabilization is further improved with an increase in electrostatic contribution. The computational analysis of the $\mathrm{Ni}(0)$ complex $\left(\mathrm{Ph}_{3} \mathrm{P}\right)_{2} \mathrm{Ni}(\mathrm{HC} \equiv \mathrm{CH})[70]$ 
was also performed for a comparison (ESI). As expected, it shows a significantly more stabilized Ni- $(\mathrm{HC} \equiv \mathrm{CH})$ bond $\left(\Delta \mathrm{E}_{\mathrm{int}}=-75.9 \mathrm{kcal} \cdot \mathrm{mol}^{-1}\right)$ owing to the increase of both electrostatic and orbital stabilizations, as given by a pronounced $\mathrm{M} \rightarrow$ alkyne backbonding, which amounts to -77.6 versus $-35.6 \mathrm{kcal} \cdot \mathrm{mol}^{-1}$ in 4 , which is consistent with the trends of red-shift of the $\mathrm{C} \equiv \mathrm{C}$ stretching frequency (or the weakening of the $\mathrm{C} \equiv \mathrm{C}$ bond).

Table 2. Energy decomposition analysis of the interaction energy in mononuclear and dinuclear $\mathrm{Cu}(\mathrm{I})$ species. Values in $\mathrm{kcal} \cdot \mathrm{mol}^{-1}$. Vibrational frequencies in $\mathrm{cm}^{-1}$.

\begin{tabular}{|c|c|c|c|c|c|c|c|c|c|c|}
\hline \multicolumn{11}{|c|}{$\begin{array}{l}\text { Mononuclear, Bis(pyrazolyl)Borate Copper Complexes, } \\
\mathrm{L}=\left[\mathrm{H}_{2} \mathrm{~B}\left(3,5-\left(\mathrm{CF}_{3}\right)_{2} \mathrm{Pz}\right)_{2}\right] ; \mathrm{L}^{\prime}=\left[\mathrm{H}_{2} \mathrm{~B}\left(4-\mathrm{Br}-3,5-\left(\mathrm{CF}_{3}\right)_{2} \mathrm{Pz}\right)_{2}\right]\end{array}$} \\
\hline & \multicolumn{2}{|c|}{$\begin{array}{l}\mathrm{LCu}(\mathrm{HC} \equiv \mathrm{CH}) \\
\mathbf{4}\end{array}$} & \multicolumn{2}{|c|}{$\begin{array}{l}\mathrm{LCu}(\mathrm{EtC} \equiv \mathrm{CEt}) \\
\mathbf{6}\end{array}$} & \multicolumn{2}{|c|}{$\begin{array}{l}\mathrm{LCu}(\mathrm{PhC} \equiv \mathrm{CH}) \\
\quad \mathbf{8}\end{array}$} & \multicolumn{2}{|c|}{$\mathrm{LCu}\left(\mathrm{HC} \equiv \mathrm{CSiMe}_{3}\right)$} & \multicolumn{2}{|c|}{$\mathrm{L}^{\prime} \mathrm{Cu}(\mathrm{HC} \equiv \mathrm{CH})$} \\
\hline$\Delta \mathrm{E}_{\text {Pauli }}$ & \multicolumn{2}{|l|}{121.8} & \multicolumn{2}{|l|}{131.0} & \multicolumn{2}{|l|}{124.8} & \multicolumn{2}{|l|}{123.6} & \multicolumn{2}{|l|}{119.9} \\
\hline$\Delta \mathrm{E}_{\text {Elstat }}$ & -100.4 & $59.5 \%$ & -112.6 & $61.7 \%$ & -102.3 & $58.8 \%$ & -103.7 & $59.0 \%$ & -99.1 & $59.5 \%$ \\
\hline$\Delta \mathrm{E}_{\text {orb }}$ & -62.2 & $36.9 \%$ & -59.9 & $32.8 \%$ & -61.8 & $35.5 \%$ & -60.3 & $34.3 \%$ & -61.5 & $36.9 \%$ \\
\hline$\Delta \mathrm{E}_{\text {Disp }}$ & -6.0 & $3.6 \%$ & -10.0 & $5.5 \%$ & -10.0 & $5.7 \%$ & -11.7 & $6.7 \%$ & -6.0 & $3.6 \%$ \\
\hline$\Delta \mathrm{E}_{\text {int }}$ & -46.8 & & -51.5 & & -49.4 & & -52.1 & & -46.7 & \\
\hline$\pi \rightarrow \mathrm{Cu}$ & -35.6 & $57.2 \%$ & -31.0 & $51.8 \%$ & -33.8 & $54.6 \%$ & -31.5 & $52.2 \%$ & -34.8 & $56.5 \%$ \\
\hline$\sigma \leftarrow \mathrm{Cu}$ & -16.3 & $26.3 \%$ & -17.5 & $29.2 \%$ & -16.6 & $26.9 \%$ & -16.7 & $27.7 \%$ & -16.5 & $26.8 \%$ \\
\hline $\begin{array}{l}v_{\mathrm{C}} \equiv \mathrm{C}, \text { Calc. } \\
\quad(\text { Exp.) }\end{array}$ & $\begin{array}{c}1817 \\
(1819)\end{array}$ & & $\begin{array}{c}2056 \\
(2064)\end{array}$ & & $\begin{array}{c}1954 \\
(1927)\end{array}$ & & $\begin{array}{l}1870 \\
(1870)\end{array}$ & & 1818 & \\
\hline \multicolumn{11}{|c|}{ Dinuclear, Copper Pyrazolate Complexes } \\
\hline & \multicolumn{2}{|c|}{$\begin{array}{c}\mathrm{Cu}_{2}\left(\mu-\left[3,5-\left(\mathrm{CF}_{3}\right)_{2} \mathrm{Pz}\right]\right)_{2}(\mathrm{HC} \equiv \mathrm{CH})_{2} \\
\mathbf{1 0}\end{array}$} & \multicolumn{2}{|c|}{$\begin{array}{c}\mathrm{Cu}_{2}(\mu-[3,5- \\
\left.\left.\left(\mathrm{CF}_{3}\right)_{2} \mathrm{Pz}\right]\right)_{2}(\mathrm{EtC} \equiv \mathrm{CEt})_{2} \\
7\end{array}$} & \multicolumn{3}{|c|}{$\mathrm{Cu}_{2}\left(\mu-\left[3,5-\left(\mathrm{CF}_{3}\right)_{2} \mathrm{Pz}\right]\right)_{2}(\mathrm{PhC} \equiv \mathrm{CH})_{2}$} & \multicolumn{3}{|c|}{$\begin{array}{c}\mathrm{Cu}_{2}\left(\mu-\left[4-\mathrm{Br}-3,5-\left(\mathrm{CF}_{3}\right)_{2} \mathrm{Pz}\right]\right)_{2}(\mathrm{HC} \equiv \mathrm{CH})_{2} \\
\mathbf{2}\end{array}$} \\
\hline$\Delta \mathrm{E}_{\text {Pauli }}$ & 128.0 & & 143.2 & & 142.0 & & & 124.6 & & \\
\hline$\Delta \mathrm{E}_{\text {Elstat }}$ & -102.7 & $59.8 \%$ & -118.2 & $61.3 \%$ & -109.8 & $57.8^{\circ}$ & & -99.9 & & \\
\hline$\Delta \mathrm{E}_{\text {orb }}$ & -62.8 & $36.5 \%$ & -62.2 & $32.3 \%$ & -65.6 & $34.5^{\circ}$ & & -61.5 & & \\
\hline$\Delta \mathrm{E}_{\text {Disp }}$ & -6.3 & $3.7 \%$ & -12.2 & $6.3 \%$ & -14.5 & $7.6 \%$ & & -6.1 & & \\
\hline$\Delta \mathrm{E}_{\mathrm{int}}$ & -43.8 & & -49.4 & & -47.8 & & & -42.9 & & \\
\hline$\pi \rightarrow \mathrm{Cu}$ & -35.8 & $57.0 \%$ & -32.3 & $52.0 \%$ & -35.7 & $54.5^{\circ}$ & & -34.8 & & \\
\hline$\sigma \leftarrow \mathrm{Cu}$ & -16.7 & $26.5 \%$ & -17.9 & $28.7 \%$ & -17.0 & $25.9^{\circ}$ & & -16.6 & & \\
\hline $\begin{array}{l}v_{\mathrm{C}} \equiv \mathrm{C}, \text { Calc. } \\
\text { (Exp.) }\end{array}$ & 1814 & & $\begin{array}{l}2055 \\
(2033 \\
2066)\end{array}$ & & 1950 & & & $\begin{array}{c}1813 \\
(1811)\end{array}$ & & \\
\hline
\end{tabular}

Considering the importance of and interest in copper catalyzed azide-alkyne cycloaddition (CuAAC), as well as the rich alkyne chemistry of " $\left[\mathrm{H}_{2} \mathrm{~B}\left(3,5-\left(\mathrm{CF}_{3}\right)_{2} \mathrm{Pz}\right)_{2}\right] \mathrm{Cu}$ " moiety, we also set out to explore the use of fluorinated bis(pyrazolyl)borate copper(I) complex $\left[\mathrm{H}_{2} \mathrm{~B}\left(3,5-\left(\mathrm{CF}_{3}\right)_{2} \mathrm{Pz}\right)_{2}\right] \mathrm{Cu}(\mathrm{NCMe})$ as a catalyst in cycloaddition of organic azides with terminal alkynes. We also compare the effectiveness of $\left[\mathrm{H}_{2} \mathrm{~B}\left(3,5-\left(\mathrm{CF}_{3}\right)_{2} \mathrm{Pz}\right)_{2}\right] \mathrm{Cu}(\mathrm{NCMe})$ with the trinuclear copper(I) pyrazolate $\left\{\mu-\left[3,5-\left(\mathrm{CF}_{3}\right)_{2} \mathrm{Pz}\right] \mathrm{Cu}\right\}_{3}[50]$, which was found to be quite an effective catalyst for these reactions [47,81]. The Huisgen 1,3-dipolar cycloaddition [82] of organic azides and alkyne received significant attention ever since Sharpless [2] and Meldal [1] independently developed a copper(I) catalyzed reaction. Multidentate nitrogen ligands such as poly(pyrazolyl)borate ligands are known for stabilizing different metal ions including $\mathrm{Cu}(\mathrm{I})[83,84]$. Ruthenium(II) tris(pyrazolyl)borates are reported to catalyze cycloaddition of organic azides and alkyne [85]. There are however very few reports on copper(I) tris(pyrazolyl)borate catalyzed azide-alkyne cycloaddition even though they are known to catalyze several reactions such as cyclopropanation, cyclopropenation, nitrene transfer reactions, etc. [86]. One of the reports concerns the synthesis of N-sulfonyl-1,2,3triazoles from $\mathrm{N}$-sulfonyl azides and alkynes [87]. That report shows copper(I) supported by tris(pyrazolyl)methanes providing better yields than the tris(pyrazolyl)borate based catalysts. More recent work by Stiriba and co-workers described the use of bis- and tris(pyrazolyl)boratocopper(I) systems to mediate reactions between phenyl- and alkyl- 
azides with different alkynes to produce 1,4-disubstituted 1,2,3-triazole derivatives moderate to excellent yields [88].

Table 3 summarizes the results of azide-alkyne cycloaddition mediated by the mononuclear $\left[\mathrm{H}_{2} \mathrm{~B}\left(3,5-\left(\mathrm{CF}_{3}\right)_{2} \mathrm{Pz}\right)_{2}\right] \mathrm{Cu}(\mathrm{NCMe})(\mathbf{1})$ and the trinuclear copper(I) pyrazolate $\{\mu-[3,5-$ $\left.\left.\left(\mathrm{CF}_{3}\right)_{2} \mathrm{Pz}\right] \mathrm{Cu}\right\}_{3}$. A reaction of $p$-tolylazide with different terminal alkynes using $1 \mathrm{~mol} \%$ of catalyst 1 at $110{ }^{\circ} \mathrm{C}$ in toluene gives a very high yield for all substrates. The control reaction of $p$-tolyl azide with phenylacetylene without catalyst at the same temperature gives a lower $(64 \%)$ yield. Thus, the temperature alone drives some of these processes albeit less effectively. We then tested the chemistry using a lower temperature but using a higher catalyst load. The use of $10 \mathrm{~mol} \%$ compound $1 \mathrm{in} \mathrm{EtOH}$ at $40^{\circ} \mathrm{C}$ gives triazoles in moderate to excellent yield including a rare $\mathrm{CuACC}$ reaction involving the acetylene gas. The control reaction without the catalyst for these conditions gives $<1 \%$ triazole (reaction of phenylacetylene and $p$-tolylazide). We compared these results to the corresponding $\left\{\mu-\left[3,5-\left(\mathrm{CF}_{3}\right)_{2} \mathrm{Pz}\right] \mathrm{Cu}\right\}_{3}$ mediated chemistry using $1 \mathrm{~mol} \%$ catalyst, at room temperature in dichloromethane. This trinuclear catalyst catalyzed alkyne-azide cycloadditions very effectively under milder conditions and generated products in high yield for all substrates except for trimethylsilylacetylene. It is noteworthy that all reactions (except $110^{\circ} \mathrm{C}$ reactions) are done in a vial using normal solvents and without using any inert atmosphere. Although we have not probed the mechanistic details, recent work by Larinov and coworkers on $\left\{\mu-\left[3,5-\left(\mathrm{CF}_{3}\right)_{2} \mathrm{Pz}\right] \mathrm{Cu}\right\}_{3}$ and Stiriba and co-workers on poly(pyrazolyl)borate copper catalyzed cycloadditions suggest different mechanisms, most notably involving tetranuclear and dinuclear intermediates, respectively, for the two systems [88,89]. Better activity of the trinuclear $\left\{\mu-\left[3,5-\left(\mathrm{CF}_{3}\right)_{2} \mathrm{Pz}\right] \mathrm{Cu}\right\}_{3}$ over mononuclear $\left[\mathrm{H}_{2} \mathrm{~B}\left(3,5-\left(\mathrm{CF}_{3}\right)_{2} \mathrm{Pz}\right)_{2}\right] \mathrm{Cu}(\mathrm{NCMe})$ in copper catalyzed azide-alkyne cycloaddition suggests that these reactions involve multicenter catalytic intermediates, consistent with proposed mechanisms [31] and having pre-assembled copper sites with bridging ligands is an advantage [49].

Table 3. Azide-alkyne cycloaddition mediated by the mononuclear bis(pyrazolyl)borate $\left[\mathrm{H}_{2} \mathrm{~B}(3,5-\right.$ $\left.\left.\left(\mathrm{CF}_{3}\right)_{2} \mathrm{Pz}\right)_{2}\right] \mathrm{Cu}(\mathrm{NCMe})(\mathbf{1})$ and the trinuclear copper(I) pyrazolate $\left\{\mu-\left[3,5-\left(\mathrm{CF}_{3}\right)_{2} \mathrm{Pz}\right] \mathrm{Cu}\right\}_{3}$. Different Methods are described in the experimental section.

\begin{tabular}{|c|c|c|c|c|}
\hline \multirow[t]{2}{*}{ Entry } & \multirow[t]{2}{*}{ Alkyne } & \multicolumn{2}{|c|}{$\begin{array}{c}\text { Yield }(\%) \\
{\left[\mathrm{H}_{2} \mathrm{~B}\left(3,5-\left(\mathrm{CF}_{3}\right)_{2} \mathrm{Pz}\right)_{2}\right] \mathrm{Cu}(\mathrm{NCMe})} \\
\text { catalyst }\end{array}$} & \multirow{2}{*}{$\begin{array}{c}\text { Yield }(\%) \\
\left\{\mu-\left[3,5-\left(\mathrm{CF}_{3}\right)_{2} \mathrm{Pz}\right] \mathrm{Cu}\right\}_{3} \text { Catalyst } \\
\text { Method III }\end{array}$} \\
\hline & & Method I & Method II & \\
\hline 1 & $\mathrm{HC} \equiv \mathrm{CH}$ & - & 80 & 99 \\
\hline 2 & $n-\operatorname{PrC} \equiv \mathrm{CH}$ & 99 & 85 & 99 \\
\hline 3 & $n-\mathrm{BuC} \equiv \mathrm{CH}$ & 99 & 89 & 99 \\
\hline 4 & $n-\mathrm{C}_{8} \mathrm{H}_{17} \mathrm{C} \equiv \mathrm{CH}$ & 99 & 91 & 99 \\
\hline 5 & $\mathrm{PhC} \equiv \mathrm{CH}$ & 99 & 84 & 99 \\
\hline 6 & $\mathrm{Me}_{3} \mathrm{SiC} \equiv \mathrm{CH}$ & 99 & 56 & 10 \\
\hline
\end{tabular}

In summary, we report the isolation and characterization of $\left[\mathrm{H}_{2} \mathrm{~B}\left(3,5-\left(\mathrm{CF}_{3}\right)_{2} \mathrm{Pz}\right)_{2}\right]$ $\mathrm{Cu}(\mathrm{HC} \equiv \mathrm{CH})$ and $\left[\mathrm{H}_{2} \mathrm{~B}\left(3,5-\left(\mathrm{CF}_{3}\right)_{2} \mathrm{Pz}\right)_{2}\right] \mathrm{Cu}\left(\mathrm{HC} \equiv \mathrm{CSiMe}_{3}\right)$ supported by a highly fluorinated bis(pyrazolyl)borate ligand. They feature three-coordinate, trigonal planar copper sites in the solid state and exhibit a significant reduction in $\bar{v}_{\mathrm{C} \equiv \mathrm{C}}$ value relative to the corresponding free alkyne $\mathrm{C} \equiv \mathrm{C}$ stretch. Computational analysis of these molecules and several other related compounds using DFT indicates that the $\mathrm{Cu}(\mathrm{I})$-alkyne interaction in these copper complexes is primarily of electrostatic character. Furthermore, despite the presence of a highly fluorinated ligand in $\left[\mathrm{H}_{2} \mathrm{~B}\left(3,5-\left(\mathrm{CF}_{3}\right)_{2} \mathrm{Pz}\right)_{2}\right] \mathrm{Cu}(\mathrm{HC} \equiv \mathrm{CH})$ 
and $\left.\left[\mathrm{H}_{2} \mathrm{~B}\left(3,5-\left(\mathrm{CF}_{3}\right)_{2} \mathrm{Pz}\right)_{2}\right] \mathrm{Cu}(\mathrm{HC} \equiv \mathrm{CSiMe})_{3}\right)$, the $\mathrm{Cu} \rightarrow$ alkyne $\pi$-backbonding component is much larger than the alkyne $\rightarrow \mathrm{Cu} \sigma$-bonding interaction. However, the backbonding is not as high as that computed for $\left(\mathrm{Ph}_{3} \mathrm{P}\right)_{2} \mathrm{Ni}(\mathrm{HC} \equiv \mathrm{CH})$. The mononuclear and dinuclear complexes such as $\left[\mathrm{H}_{2} \mathrm{~B}\left(3,5-\left(\mathrm{CF}_{3}\right)_{2} \mathrm{Pz}\right)_{2}\right] \mathrm{Cu}(\mathrm{HC} \equiv \mathrm{CH})$ and $\mathrm{Cu}_{2}\left(\mu-\left[3,5-\left(\mathrm{CF}_{3}\right)_{2} \mathrm{Pz}\right]\right)_{2}(\mathrm{HC} \equiv \mathrm{CH})_{2}$ display similar $\mathrm{Cu}$-alkyne bonding features. The bis(pyrazolyl)borate complex $\left[\mathrm{H}_{2} \mathrm{~B}(3,5-\right.$ $\left.\left.\left(\mathrm{CF}_{3}\right)_{2} \mathrm{Pz}\right)_{2}\right] \mathrm{Cu}(\mathrm{NCMe})$ catalyzes [3+2] cycloaddition chemistry between tolyl azide and a variety of alkynes including acetylene to produce 1,2,3-triazoles. It is, however, comparatively less effective than the related trinuclear copper catalyst $\left\{\mu-\left[3,5-\left(\mathrm{CF}_{3}\right)_{2} \mathrm{Pz}\right] \mathrm{Cu}\right\}_{3}$ involving bridging pyrazolates. We are presently exploring the metal mediated alkene and alkyne chemistry supported by these and other fluorinated ligands [90,91].

\section{Experimental Details}

All manipulations except catalysis were carried out under an atmosphere of purified nitrogen using standard Schlenk techniques or in a MBraun glovebox equipped with a $-25{ }^{\circ} \mathrm{C}$ refrigerator. Solvents were purchased from commercial sources, purified prior to use. NMR spectra were recorded at $25{ }^{\circ} \mathrm{C}$ on a JEOL Eclipse 500 spectrometer (Peabody, MA, USA) $\left({ }^{1} \mathrm{H}, 500.16 \mathrm{MHz} ;{ }^{13} \mathrm{C}, 125.78 \mathrm{MHz} ;{ }^{19} \mathrm{~F}, 470.62 \mathrm{MHz}\right)$ unless otherwise noted. Proton and carbon chemical shifts are reported in ppm versus $\mathrm{Me}_{4} \mathrm{Si} .{ }^{1} \mathrm{H} \mathrm{NMR}$ coupling constants $(\mathrm{J})$ are reported in Hertz $(\mathrm{Hz})$ and multiplicities are indicated as follows: $\mathrm{s}$ (singlet), d (doublet), $\mathrm{t}$ (triplet), $\mathrm{m}$ (multiplet). ${ }^{19} \mathrm{~F}$ NMR values were referenced to external $\mathrm{CFCl}_{3}$. Melting points were obtained on a Mel-Temp II apparatus (Wayne, PA, USA) and were not corrected. Elemental analyses were performed using a Perkin-Elmer Model $2400 \mathrm{CHN}$ analyzer (Waltham, MA, USA). IR spectra were collected at room temperature on a Shimadzu IR Prestige-21 FTIR (Kyoto, Japan) containing an ATR attachment using pure liquid or solid materials, with instrument resolution at $2 \mathrm{~cm}^{-1}$. Raman data were collected on a Horiba Jobin Yvon LabRAM Aramin Raman spectrometer (Edison, NJ, USA) with a HeNe laser source of $633 \mathrm{~nm}$, by placing pure liquid or solid materials on a glass slide/cuvette. Heating was accomplished by either a heating mantle or a silicone oil bath. Purification of reaction products was carried out by flash column chromatography using silica gel 60 (230-400 mesh). TLC visualization was accompanied by UV light or $\mathrm{KMnO}_{4}$ stains. The $\left[\mathrm{H}_{2} \mathrm{~B}\left(3,5-\left(\mathrm{CF}_{3}\right)_{2} \mathrm{Pz}\right)_{2}\right] \mathrm{Cu}(\mathrm{NCMe})(\mathbf{1})[42]$ and $\left\{\mu-\left[3,5-\left(\mathrm{CF}_{3}\right)_{2} \mathrm{Pz}\right] \mathrm{Cu}\right\}_{3}[50]$ were prepared according to reported literature procedures. $p$-Tolyl azide was prepared according to the literature procedure [92]. All other reactants and reagents were purchased from commercial sources. Acetylene gas was freed from acetone and purified before use [61]. All other reactants and reagents were purchased from commercial sources.

Warning. Due care must be taken when working with acetylene gas. It is known to produce explosive combinations with oxygen, and also form potentially explosive acetylides and other materials with copper salts [62].

$\left[\mathrm{H}_{2} \mathrm{~B}\left(3,5-\left(\mathrm{CF}_{3}\right)_{2} \mathrm{Pz}\right)_{2}\right] \mathrm{Cu}(\mathrm{HC} \equiv \mathrm{CH})(4):\left[\mathrm{H}_{2} \mathrm{~B}\left(3,5-\left(\mathrm{CF}_{3}\right)_{2} \mathrm{Pz}\right)_{2}\right] \mathrm{Cu}(\mathrm{NCMe})(0.15 \mathrm{~g}, 0.29 \mathrm{mmol})$ was dissolved in $7 \mathrm{~mL}$ dichloromethane and stirred for $\sim 10 \mathrm{~min}$ while bubbling acetylene. The reaction mixture was concentrated with continuous flow of acetylene and kept at $-20{ }^{\circ} \mathrm{C}$ to obtain X-ray quality colorless crystals of $\left[\mathrm{H}_{2} \mathrm{~B}\left(3,5-\left(\mathrm{CF}_{3}\right)_{2} \mathrm{Pz}\right)_{2}\right] \mathrm{Cu}(\mathrm{HC} \equiv \mathrm{CH})$. Yield: $>90 \%$. M.P.: $78-79{ }^{\circ}$ C. Anal. Calc. $\mathrm{C}_{12} \mathrm{H}_{6} \mathrm{BCuF}_{12} \mathrm{~N}_{4}$ : C, 28.34\%; H, 1.19\%; N, 11.02\%. Found: C, 28.18\%; H, 1.17\%; N, 11.04\%. ${ }^{1} \mathrm{H} \mathrm{NMR}\left(\mathrm{CDCl}_{3}\right): \delta(\mathrm{ppm}) 6.93(\mathrm{~s}, 2 \mathrm{H}, \mathrm{PzH}), 4.70(\mathrm{~s}$, $2 \mathrm{H}, \equiv \mathrm{CH}), 4.00(\mathrm{br}, 2 \mathrm{H}, \mathrm{BH}) .{ }^{19} \mathrm{~F}$ NMR $\left(\mathrm{CDCl}_{3}\right): \delta(\mathrm{ppm})-59.8(\mathrm{~s}),-60.7(\mathrm{~s}) .{ }^{13} \mathrm{C}\left\{{ }^{1} \mathrm{H}\right\} \mathrm{NMR}$ $\left(\mathrm{CDCl}_{3}\right): \delta(\mathrm{ppm}) 142.2\left(\mathrm{q},{ }^{2} J_{\mathrm{C}-\mathrm{F}}=39.6 \mathrm{~Hz}, \mathrm{C}-3 / \mathrm{C}-5\right), 139.9\left(\mathrm{q},{ }^{2} J_{\mathrm{C}-\mathrm{F}}=41.2 \mathrm{~Hz}, \mathrm{C}-3 / \mathrm{C}-5\right)$, $120.1\left(\mathrm{q},{ }^{1} J_{\mathrm{C}-\mathrm{F}}=268.7 \mathrm{~Hz}, \mathrm{CF}_{3}\right), 119.2\left(\mathrm{q},{ }^{1} J_{\mathrm{C}-\mathrm{F}}=271.1 \mathrm{~Hz}, \mathrm{CF}_{3}\right), 106.4(\mathrm{C}-4), 80.2(\mathrm{C} \equiv \mathrm{C})$. ${ }^{13} \mathrm{C}\left({ }^{1} \mathrm{H}\right.$ coupled) NMR $\left(\mathrm{CDCl}_{3}\right): \delta(\mathrm{ppm}) 142.2\left(\mathrm{q},{ }^{2} J_{\mathrm{C}-\mathrm{F}}=38.4 \mathrm{~Hz}, \mathrm{C}-3 / \mathrm{C}-5\right), 139.9(\mathrm{q}$, $\left.{ }^{2} J_{\mathrm{C}-\mathrm{F}}=40.8 \mathrm{~Hz}, \mathrm{C}-3 / \mathrm{C}-5\right), 120.1\left(\mathrm{q},{ }^{1} J_{\mathrm{C}-\mathrm{F}}=268.7 \mathrm{~Hz}, \mathrm{CF}_{3}\right), 119.2\left(\mathrm{q},{ }^{1} J_{\mathrm{C}-\mathrm{F}}=271.1 \mathrm{~Hz}, \mathrm{CF}_{3}\right)$, $106.4\left(\mathrm{~d},{ }^{1} J_{\mathrm{C}-\mathrm{H}}=187.1 \mathrm{~Hz}, \mathrm{C}-4\right), 80.3\left(\mathrm{dd},{ }^{1} J_{\mathrm{C}-\mathrm{H}}=251.9 \mathrm{~Hz},{ }^{2} J_{\mathrm{C}-\mathrm{H}}=43.2 \mathrm{~Hz}, \mathrm{C} \equiv \mathrm{C}\right) . \mathrm{Ra}-$ man $\left(\mathrm{cm}^{-1}\right)$, selected peak: $1819(\mathrm{C} \equiv \mathrm{C})$.

$\left[\mathrm{H}_{2} \mathrm{~B}\left(3,5-\left(\mathrm{CF}_{3}\right)_{2} \mathrm{Pz}\right)_{2}\right] \mathrm{Cu}\left(\mathrm{HC} \equiv \mathrm{CSiMe}_{3}\right)(5):\left[\mathrm{H}_{2} \mathrm{~B}\left(3,5-\left(\mathrm{CF}_{3}\right)_{2} \mathrm{Pz}\right)_{2}\right] \mathrm{Cu}(\mathrm{NCMe})(0.15 \mathrm{~g}, 0.29 \mathrm{mmol})$ was dissolved in $7 \mathrm{~mL}$ dichloromethane. Trimethylsilylacetylene $(48 \mu \mathrm{L}, 0.35 \mathrm{mmol})$ was added to the reaction mixture and stirred overnight. The solvent was evaporated to get 
white powder product. The product was dissolved in dichloromethane and kept at $-20{ }^{\circ} \mathrm{C}$ to obtain X-ray quality colorless crystals of $\left[\mathrm{H}_{2} \mathrm{~B}\left(3,5-\left(\mathrm{CF}_{3}\right)_{2} \mathrm{Pz}\right)_{2}\right] \mathrm{Cu}(\mathrm{HC} \equiv \mathrm{CSiMe})_{3}$. Yield: 91\%. M.P.: 59-61 ${ }^{\circ} \mathrm{C}$. Anal. Calc. $\mathrm{C}_{15} \mathrm{H}_{14} \mathrm{BCuF}_{12} \mathrm{~N}_{4} \mathrm{Si}: \mathrm{C}, 31.02 \% ; \mathrm{H}, 2.43 \%$; N, 9.65\%. Found: C, 30.64\%; H, 2.07\%; N, 9.98\%. ${ }^{1} \mathrm{H} \mathrm{NMR}\left(\mathrm{CDCl}_{3}\right): \delta$ (ppm) 6.88 (s, 2H, PzH), 4.81 (s, $1 \mathrm{H}, \equiv \mathrm{CH}), 3.92(\mathrm{br}, 2 \mathrm{H}, \mathrm{BH}), 0.24\left(\mathrm{~s}, 9 \mathrm{H}, \mathrm{Si}\left(\mathrm{CH}_{3}\right)_{3}\right) .{ }^{19} \mathrm{~F} \mathrm{NMR}\left(\mathrm{CDCl}_{3}\right): \delta(\mathrm{ppm})-59.9$ (s), -61.0 (s). ${ }^{13} \mathrm{C}\left\{{ }^{1} \mathrm{H}\right\} \mathrm{NMR}\left(\mathrm{CDCl}_{3}\right): \delta(\mathrm{ppm}) 141.8\left(\mathrm{q},{ }^{2} J_{\mathrm{C}-\mathrm{F}}=38.4 \mathrm{~Hz}, \mathrm{C}-3 / \mathrm{C}-5\right), 139.8\left(\mathrm{q},{ }^{2} J_{\mathrm{C}-\mathrm{F}}\right.$ $=43.2 \mathrm{~Hz}, \mathrm{C}-3 / \mathrm{C}-5), 120.2\left(\mathrm{q},{ }^{1} J_{\mathrm{C}-\mathrm{F}}=269.9 \mathrm{~Hz}, \mathrm{CF}_{3}\right), 119.3\left(\mathrm{q},{ }^{1} J_{\mathrm{C}-\mathrm{F}}=269.9 \mathrm{~Hz}, \mathrm{CF}_{3}\right), 106.2$ (C-4), $97.8(\mathrm{C} \equiv \mathrm{C}), 97.2(\mathrm{C} \equiv \mathrm{C}),-0.2\left(\mathrm{SiCH}_{3}\right)$. Raman $\left(\mathrm{cm}^{-1}\right)$, selected peak: $1870(\mathrm{C} \equiv \mathrm{C})$.

$\left[\mathrm{H}_{2} \mathrm{~B}\left(3,5-\left(\mathrm{CF}_{3}\right)_{2} \mathrm{Pz}\right)_{2}\right] \mathrm{Cu}(\mathrm{EtC} \equiv \mathrm{CEt})(6)$ : This was synthesized as reported earlier[6] and crystallized using dichloromethane at $-20{ }^{\circ} \mathrm{C}$ to obtain crystals suitable for $\mathrm{X}$-ray analysis.

Details of CuACC chemistry involving several alkynes and $p$-tolyl azide

1. General method I for the synthesis of triazoles:

A $50 \mathrm{~mL}$ Schlenk flask was charged with the selected alkyne (1.0. mmol), $\left[\mathrm{H}_{2} \mathrm{~B}(3,5-\right.$ $\left.\left.\left(\mathrm{CF}_{3}\right)_{2} \mathrm{Pz}\right)_{2}\right] \mathrm{Cu}(\mathrm{NCMe})(1 \mathrm{~mol} \%)$ and toluene $(5.0 \mathrm{~mL})$ under a nitrogen atmosphere. $p$-tolyl azide $(1.0 \mathrm{mmol})$ was added to the reaction and stirred at $110{ }^{\circ} \mathrm{C}$ for $12 \mathrm{~h}$. The solvent was removed under reduced pressure. The residue was dissolved in dichloromethane and filtered through a celite. The dichloromethane was evaporated to get pure product.

2. General method II for the synthesis of triazoles:

A round bottom flask was charged with the selected alkyne (1.0. mmol), p-tolyl azide $(1.0 \mathrm{mmol})$, and $\mathrm{EtOH}(5.0 \mathrm{~mL}) \cdot\left[\mathrm{H}_{2} \mathrm{~B}\left(3,5-\left(\mathrm{CF}_{3}\right)_{2} \mathrm{Pz}\right)_{2}\right] \mathrm{Cu}(\mathrm{NCMe})(10 \mathrm{~mol} \%)$ was added to the reaction and stirred at $40{ }^{\circ} \mathrm{C}$ for $12 \mathrm{~h}$. The solvent was evaporated. The product was isolated using column chromatography (Ethyl acetate/hexanes).

3. General method III for the synthesis of triazoles

A $5 \mathrm{~mL}$ vial was charged with selected alkyne (1.0. $\mathrm{mmol})$, p-tolyl azide (1.0 mmol), and dichloromethane $(3.0 \mathrm{~mL}) .\left\{\mu-\left[3,5-\left(\mathrm{CF}_{3}\right)_{2} \mathrm{Pz}\right] \mathrm{Cu}\right\}_{3}(1 \mathrm{~mol} \%)$ was added to the reaction and stirred at room temperature for $12 \mathrm{~h}$. The yield was calculated using 1,3,5(trimethoxy)benzene as internal standard.

\section{X-ray Data Collection and Structure Determinations}

A suitable crystal covered with a layer of hydrocarbon/Paratone-N oil was selected and mounted on a Cryo-loop and immediately placed in the low temperature nitrogen stream. The X-ray intensity data were measured at 100(2) K on a Bruker D8 Quest with a Photon 100 CMOS detector equipped with an Oxford Cryosystems (Billerica, MA, USA) 700 series cooler, a graphite monochromator, and a Mo $\mathrm{K} \alpha$ fine-focus sealed tube $(\lambda=0.71073 \AA)$. Intensity data were processed using the Bruker Apex program suite. Absorption corrections were applied by using SADABS [93]. Initial atomic positions were located by SHELXT [94] and the structures of the compounds were refined by the leastsquares method using SHELXL [95] within Olex2 GUI [96]. All the non-hydrogen atoms were refined anisotropically. The hydrogen atoms of $\mathrm{BH}_{2}$ moieties as well as acetylenic $\mathrm{C} \equiv \mathrm{C} \underline{\mathrm{H}}$ were located in difference Fourier maps, included and refined freely with isotropic displacement parameters. The remaining hydrogen atoms were included in their calculated positions and refined as riding on the atoms to which they are joined. X-ray structural figures were generated using Olex2 [96]. The CCDC 2065196-2065198 files contain the supplementary crystallographic data of $\left[\mathrm{H}_{2} \mathrm{~B}\left(3,5-\left(\mathrm{CF}_{3}\right)_{2} \mathrm{Pz}\right)_{2}\right] \mathrm{Cu}(\mathrm{HC} \equiv \mathrm{CH})(4),\left[\mathrm{H}_{2} \mathrm{~B}(3,5-\right.$ $\left.\left.\left(\mathrm{CF}_{3}\right)_{2} \mathrm{Pz}\right)_{2}\right] \mathrm{Cu}(\mathrm{HC} \equiv \mathrm{CSiMe})(5)$ and $\left[\mathrm{H}_{2} \mathrm{~B}\left(3,5-\left(\mathrm{CF}_{3}\right)_{2} \mathrm{Pz}\right)_{2}\right] \mathrm{Cu}(\mathrm{EtC} \equiv \mathrm{CEt})$ (6) [6]. These data can be obtained free of charge via http:/ / www.ccdc.cam.ac.uk/conts/retrieving.html (accessed on 7 December 2021) or from the Cambridge Crystallographic Data Centre (CCDC), 12 Union Road, Cambridge, CB2 1EZ, UK). Additional details are provided in the Supporting Information section. 


\section{Theoretical Methods}

Computational details are given as Supporting information.

Supplementary Materials: The following are available online, Table S1. Selected bond distances $(\AA)$ and angles $\left(^{\circ}\right)$ and $\mathrm{C} \equiv \mathrm{C}$ stretching frequency for mononuclear $\left[\mathrm{H}_{2} \mathrm{~B}\left(3,5-\left(\mathrm{CF}_{3}\right)_{2} \mathrm{Pz}\right)_{2}\right] \mathrm{Cu}(\mathrm{HC} \equiv \mathrm{CH})$ (4), $\left[\mathrm{H}_{2} \mathrm{~B}\left(3,5-\left(\mathrm{CF}_{3}\right)_{2} \mathrm{Pz}\right)_{2}\right] \mathrm{Cu}(\mathrm{EtC} \equiv \mathrm{CEt})(6)$, and $\left[\mathrm{H}_{2} \mathrm{~B}\left(3,5-\left(\mathrm{CF}_{3}\right)_{2} \mathrm{Pz}\right)_{2}\right] \mathrm{Cu}(\mathrm{PhC} \equiv \mathrm{CH})$ (8) (top-row of figures below from $\mathrm{L}$ to $\mathrm{R})$, and dinuclear $\mathrm{Cu}_{2}\left(\mu-\left[4-\mathrm{Br}-3,5-\left(\mathrm{CF}_{3}\right)_{2} \mathrm{Pz}\right]\right)_{2}(\mathrm{HC} \equiv \mathrm{CH})_{2}(2), \mathrm{Cu}_{2}(\mu-[3,5-$ $\left.\left.\left(\mathrm{CF}_{3}\right)_{2} \mathrm{Pz}\right]\right)_{2}(\mathrm{EtC} \equiv \mathrm{CEt})_{2}(7)$, and $\mathrm{Cu}_{2}\left(\mu-\left[3,5-\left(\mathrm{CF}_{3}\right)_{2} \mathrm{Pz}\right]\right)_{2}(\mathrm{HC} \equiv \mathrm{CPh})_{2}$ (9) (bottom-row of figures below from $\mathrm{L}$ to $\mathrm{R})$, Table $\mathrm{S} 2$. Selected NMR spectroscopic $(\mathrm{RC} \equiv \mathrm{CR})$ and $\mathrm{C} \equiv \mathrm{C}$ stretching frequency data, Figure S1. ${ }^{1} \mathrm{H}$ NMR spectrum of $\left[\mathrm{H}_{2} \mathrm{~B}\left\{3,5-\left(\mathrm{CF}_{3}\right)_{2} \mathrm{Pz}\right] \mathrm{Cu}(\mathrm{HC} \equiv \mathrm{CH})(4)\right.$ in $\mathrm{CDCl}_{3}$, Figure S2: ${ }^{13} \mathrm{C}\{1 \mathrm{H}\}$ NMR spectrum of $\left[\mathrm{H}_{2} \mathrm{~B}\left\{3,5-\left(\mathrm{CF}_{3}\right)_{2} \mathrm{Pz}\right] \mathrm{Cu}(\mathrm{HC} \equiv \mathrm{CH})(4)\right.$ in $\mathrm{CDCl}_{3}$, Figure $33 .{ }^{13} \mathrm{C}\left({ }^{1} \mathrm{H}\right.$ coupled) NMR spectrum of $\left[\mathrm{H}_{2} \mathrm{~B}\left\{3,5-\left(\mathrm{CF}_{3}\right)_{2} \mathrm{Pz}\right] \mathrm{Cu}(\mathrm{HC} \equiv \mathrm{CH})(4)\right.$ in $\mathrm{CDCl}_{3}$, Figure S4. ${ }^{19} \mathrm{~F}$ NMR spectrum of $\left[\mathrm{H}_{2} \mathrm{~B}\left\{3,5-\left(\mathrm{CF}_{3}\right)_{2} \mathrm{Pz}\right] \mathrm{Cu}(\mathrm{HC} \equiv \mathrm{CH})(4)\right.$ in $\mathrm{CDCl}_{3}$, Figure S5. Raman spectrum of $\left[\mathrm{H}_{2} \mathrm{~B}\{3,5-\right.$ $\left.\left(\mathrm{CF}_{3}\right)_{2} \mathrm{Pz}\right] \mathrm{Cu}(\mathrm{HC} \equiv \mathrm{CH})(4)$, Figure $\mathrm{S} 6 .{ }^{1} \mathrm{H}$ NMR spectrum of $\left[\mathrm{H}_{2} \mathrm{~B}\left\{3,5-\left(\mathrm{CF}_{3}\right)_{2} \mathrm{Pz}\right] \mathrm{Cu}(\mathrm{HC} \equiv \mathrm{CSiMe})_{3}\right)$ (5) in $\mathrm{CDCl}_{3}$, Figure S7. ${ }^{13} \mathrm{C}\left\{{ }^{1} \mathrm{H}\right\}$ NMR spectrum of $\left[\mathrm{H}_{2} \mathrm{~B}\left\{3,5-\left(\mathrm{CF}_{3}\right)_{2} \mathrm{Pz}\right] \mathrm{Cu}(\mathrm{HC} \equiv \mathrm{CSiMe})_{3}\right)$ (5) in $\mathrm{CDCl}_{3}$, Figure $58 .{ }^{19} \mathrm{~F}$ NMR spectrum of $\left[\mathrm{H}_{2} \mathrm{~B}\left\{3,5-\left(\mathrm{CF}_{3}\right)_{2} \mathrm{Pz}\right] \mathrm{Cu}\left(\mathrm{HC} \equiv \mathrm{CSiMe}_{3}\right)(5)\right.$ in $\mathrm{CDCl}_{3}$, Figure S9. Raman spectrum of $\left[\mathrm{H}_{2} \mathrm{~B}\left\{3,5-\left(\mathrm{CF}_{3}\right)_{2} \mathrm{Pz}\right] \mathrm{Cu}\left(\mathrm{HC} \equiv \mathrm{CSiMe}_{3}\right)(5)\right.$, Figure S10. ${ }^{1} \mathrm{H}$ NMR spectrum of 1-(p-tolyl)-1H-1,2,3-triazole in $\mathrm{CDCl}_{3}$, Figure $\mathrm{S11}$. ${ }^{13} \mathrm{C}\left\{{ }^{1} \mathrm{H}\right\}$ NMR spectrum of 1-(p-tolyl)-1H1,2,3-triazole in $\mathrm{CDCl}_{3}$, Figure S12. ${ }^{1} \mathrm{H}$ NMR spectrum of 4-propyl-1-(p-tolyl)-1H-1,2,3-triazole in $\mathrm{CDCl}_{3}$, Figure S13. ${ }^{13} \mathrm{C}\left\{{ }^{1} \mathrm{H}\right\}$ NMR spectrum of 4-propyl-1-(p-tolyl)-1H-1,2,3-triazole in $\mathrm{CDCl}_{3}$, Figure S14. ${ }^{1} \mathrm{H}$ NMR spectrum of 4-butyl-1-(p-tolyl)-1H-1,2,3-triazole in $\mathrm{CDCl}_{3}$, Figure S15. ${ }^{13} \mathrm{C}\left\{{ }^{1} \mathrm{H}\right\}$ NMR spectrum of 4-butyl-1-(p-tolyl)-1H-1,2,3-triazole in $\mathrm{CDCl}_{3}$, Figure S16. ${ }^{1} \mathrm{H}$ NMR spectrum of 4-octyl-1-(p-tolyl)-1H-1,2,3-triazole in $\mathrm{CDCl}_{3}$, Figure S17. ${ }^{13} \mathrm{C}\left\{{ }^{1} \mathrm{H}\right\}$ NMR spectrum of 4-octyl-1-(ptolyl)-1H-1,2,3-triazole in $\mathrm{CDCl}_{3}$, Figure S18. ${ }^{1} \mathrm{H}$ NMR spectrum of 4-phenyl-1-(p-tolyl)-1H-1,2,3triazole in $\mathrm{CDCl}_{3}$, Figure S19. ${ }^{13} \mathrm{C}\left\{{ }^{1} \mathrm{H}\right\}$ NMR spectrum of 4-phenyl-1-(p-tolyl)-1H-1,2,3-triazole in $\mathrm{CDCl}_{3}$, Figure S20. ${ }^{1} \mathrm{H}$ NMR spectrum of 1-(p-tolyl)-4-(trimethylsilyl)-1H-1,2,3-triazole in $\mathrm{CDCl}_{3}$, Figure S21. ${ }^{13} \mathrm{C}\left\{{ }^{1} \mathrm{H}\right\}$ NMR spectrum of 1-(p-tolyl)-4-(trimethylsilyl)-1H-1,2,3-triazole in $\mathrm{CDCl}_{3}$, Figure S22. Molecular structure of $\left[\mathrm{H}_{2} \mathrm{~B}\left(3,5-\left(\mathrm{CF}_{3}\right)_{2} \mathrm{Pz}\right)_{2}\right] \mathrm{Cu}(\mathrm{HC} \equiv \mathrm{CH})(4)$, Table S3. Crystal data and structure refinement for $\left[\mathrm{H}_{2} \mathrm{~B}\left(3,5-\left(\mathrm{CF}_{3}\right)_{2} \mathrm{Pz}\right)_{2}\right] \mathrm{Cu}(\mathrm{HC} \equiv \mathrm{CH})(4)$. Table $\mathrm{S} 4$. Bond Lengths for $\left[\mathrm{H}_{2} \mathrm{~B}(3,5-\right.$ $\left.\left.\left(\mathrm{CF}_{3}\right)_{2} \mathrm{Pz}\right)_{2}\right] \mathrm{Cu}(\mathrm{HC} \equiv \mathrm{CH})(4)$, Table S5. Bond Angles for $\left[\mathrm{H}_{2} \mathrm{~B}\left(3,5-\left(\mathrm{CF}_{3}\right)_{2} \mathrm{Pz}\right)_{2}\right] \mathrm{Cu}(\mathrm{HC} \equiv \mathrm{CH})(4)$, Figure S23. Molecular structure of $\left[\mathrm{H}_{2} \mathrm{~B}\left(3,5-\left(\mathrm{CF}_{3}\right)_{2} \mathrm{Pz}\right)_{2}\right] \mathrm{Cu}\left(\mathrm{HC} \equiv \mathrm{CSiMe}_{3}\right)(5)$, Table S6. Crystal data and structure refinement for $\left[\mathrm{H}_{2} \mathrm{~B}\left(3,5-\left(\mathrm{CF}_{3}\right)_{2} \mathrm{Pz}\right)_{2}\right] \mathrm{Cu}\left(\mathrm{HC} \equiv \mathrm{CSiMe}_{3}\right)(5)$, Table S7. Bond Lengths for $\left[\mathrm{H}_{2} \mathrm{~B}(3,5-\right.$ $\left.\left.\left(\mathrm{CF}_{3}\right)_{2} \mathrm{Pz}\right)_{2}\right] \mathrm{Cu}(\mathrm{HC} \equiv \mathrm{CSiMe} 3)(5)$, Table S8. Bond Angles for $\left[\mathrm{H}_{2} \mathrm{~B}\left(3,5-\left(\mathrm{CF}_{3}\right)_{2} \mathrm{Pz}\right)_{2}\right] \mathrm{Cu}(\mathrm{HC} \equiv \mathrm{CSiMe} 3)(5)$, Figure S24. Molecular structure of $\left[\mathrm{H}_{2} \mathrm{~B}\left(3,5-\left(\mathrm{CF}_{3}\right)_{2} \mathrm{Pz}\right)_{2}\right] \mathrm{Cu}(\mathrm{EtC} \equiv \mathrm{CEt})(6)$, Table S9. Crystal data and structure refinement for $\left[\mathrm{H}_{2} \mathrm{~B}\left(3,5-\left(\mathrm{CF}_{3}\right)_{2} \mathrm{Pz}\right)_{2}\right] \mathrm{Cu}(\mathrm{EtC} \equiv \mathrm{CEt})(6)$, Table S10. Bond Lengths for $\left[\mathrm{H}_{2} \mathrm{~B}(3,5-\right.$ $\left.\left.\left(\mathrm{CF}_{3}\right)_{2} \mathrm{Pz}\right)_{2}\right] \mathrm{Cu}(\mathrm{EtC} \equiv \mathrm{CEt})(6)$, Table S11. Bond Angles for $\left[\mathrm{H}_{2} \mathrm{~B}\left(3,5-\left(\mathrm{CF}_{3}\right)_{2} \mathrm{Pz}\right)_{2}\right] \mathrm{Cu}(\mathrm{EtC} \equiv \mathrm{CEt})(6)$, Figure S25. Raman spectrum of Trimethylsilylacetylene, Figure S26. Raman spectrum of 3-hexyne, Figure S27. Raman spectrum of Phenylacetylene, Table S12. Energy decomposition analysis of the interaction energy for $\left(\mathrm{Ph}_{3} \mathrm{P}\right)_{2} \mathrm{Ni}(\mathrm{HC} \equiv \mathrm{CH})$ species accounting for the acetylene coordination. Values in $\mathrm{kcal} \cdot \mathrm{mol}^{-1}$. Vibrational frequencies in $\mathrm{cm}^{-1}$. Experimental value from [23], Figure S28. Deformation densities account for the $\pi$-backbonding (left) and $\sigma$-donation (right) contribution to the bonding scheme in the formation of $\left(\mathrm{Ph}_{3} \mathrm{P}\right)_{2} \mathrm{Ni}(\mathrm{HC} \equiv \mathrm{CH})$. Charge flow from red to blue.

Author Contributions: Conceptualization: H.V.R.D.; Crystallography: H.V.R.D.; Investigation: A.N.P., A.M.-C. and H.V.R.D.; Synthesis: A.N.-P.; Computational analysis, A.M.-C.; Writing and Validation: A.N.-P., A.M.-C. and H.V.R.D.; Project administration: H.V.R.D. All authors have read and agreed to the published version of the manuscript.

Funding: This research was funded by Welch Foundation (Grant Y-1289). A.M.-C. thanks support from FONDECYT 1180683.

Institutional Review Board Statement: Not applicable.

Informed Consent Statement: Not applicable.

Conflicts of Interest: The authors declare no conflict of interest.

Sample Availability: Samples of the compounds are not available from authors. Synthetic details are in the experimental section. 


\section{References}

1. Tornøe, C.W.; Christensen, C.; Meldal, M. Peptidotriazoles on Solid Phase: [1,2,3]-Triazoles by Regiospecific Copper(I)-Catalyzed 1,3-Dipolar Cycloadditions of Terminal Alkynes to Azides. J. Org. Chem. 2002, 67, 3057-3064. [CrossRef]

2. Rostovtsev, V.V.; Green, L.G.; Fokin, V.V.; Sharpless, K.B. A Stepwise Huisgen Cycloaddition Process: Copper(I)-Catalyzed Regioselective "Ligation" of Azides and Terminal Alkynes. Angew. Chem. Int. Ed. 2002, 41, 2596-2599. [CrossRef]

3. Amblard, F.; Cho, J.H.; Schinazi, R.F. Cu(I)-Catalyzed Huisgen Azide-Alkyne 1,3-Dipolar Cycloaddition Reaction in Nucleoside, Nucleotide, and Oligonucleotide Chemistry. Chem. Rev. 2009, 109, 4207-4220. [CrossRef] [PubMed]

4. Neto, J.S.S.; Zeni, G. A decade of advances in the reaction of nitrogen sources and alkynes for the synthesis of triazoles. Coord. Chem. Rev. 2020, 409, 213217. [CrossRef]

5. Leophairatana, P.; Samanta, S.; De Silva, C.C.; Koberstein, J.T. Preventing Alkyne-Alkyne (i.e., Glaser) Coupling Associated with the ATRP Synthesis of Alkyne-Functional Polymers/Macromonomers and for Alkynes under Click (i.e., CuAAC) Reaction Conditions. J. Am. Chem. Soc. 2017, 139, 3756-3766. [CrossRef] [PubMed]

6. Noonikara-Poyil, A.; Ridlen, S.G.; Dias, H.V.R. Isolable Copper(I) $\eta^{2}$-Cyclopropene Complexes. Inorg. Chem. 2020, 59, 17860-17865. [CrossRef] [PubMed]

7. Chen, L.; Leslie, D.; Coleman, M.G.; Mack, J. Recyclable heterogeneous metal foil-catalyzed cyclopropenation of alkynes and diazoacetates under solvent-free mechanochemical reaction conditions. Chem. Sci. 2018, 9, 4650-4661. [CrossRef] [PubMed]

8. Diaz-Requejo, M.M.; Mairena, M.A.; Belderrain, T.R.; Nicasio, M.C.; Trofimenko, S.; Perez, P.J. A family of highly active copper(I)homoscorpionate catalysts for the alkyne cyclopropenation reaction. Chem. Commun. 2001, 1804-1805. [CrossRef] [PubMed]

9. Shi, X.; Lin, Y.; Huang, L.; Sun, Z.; Yang, Y.; Zhou, X.; Vovk, E.; Liu, X.; Huang, X.; Sun, M.; et al. Copper Catalysts in Semihydrogenation of Acetylene: From Single Atoms to Nanoparticles. ACS Catal. 2020, 10, 3495-3504. [CrossRef]

10. Redfern, L.R.; Lo, W.-S.; Dillingham, I.J.; Eatman, J.G.; Mian, M.R.; Tsung, C.-K.; Farha, O.K. Enhancing Four-Carbon Olefin Production from Acetylene over Copper Nanoparticles in Metal-Organic Frameworks. ACS Appl. Mater. Interfaces 2020, 12, 31496-31502. [CrossRef]

11. Alonso, F.; Beletskaya, I.P.; Yus, M. Transition-metal-catalyzed addition of heteroatom-hydrogen bonds to alkynes. Chem. Rev. 2004, 104, 3079-3159. [CrossRef]

12. Whyte, A.; Torelli, A.; Mirabi, B.; Zhang, A.; Lautens, M. Copper-Catalyzed Borylative Difunctionalization of $\pi$-Systems. ACS Catal. 2020, 10, 11578-11622. [CrossRef]

13. Fujihara, T.; Xu, T.; Semba, K.; Terao, J.; Tsuji, Y. Copper-Catalyzed Hydrocarboxylation of Alkynes Using Carbon Dioxide and Hydrosilanes. Angew. Chem. Int. Ed. 2011, 50, 523-527. [CrossRef]

14. Zhao, C.; Zhang, X.; He, Z.; Guan, Q.; Li, W. Demystifying the mechanism of NMP ligands in promoting Cu-catalyzed acetylene hydrochlorination: Insights from a density functional theory study. Inorg. Chem. Front. 2020, 7, 3204-3216. [CrossRef]

15. Dondoni, A.; Marra, A. Metal-catalyzed and metal-free alkyne hydrothiolation: Synthetic aspects and application trends. Eur. J. Org. Chem. 2014, 2014, 3955-3969. [CrossRef]

16. Grirrane, A.; Alvarez, E.; Garcia, H.; Corma, A. Synthesis, Structure, Reactivity and Catalytic Implications of a Cationic, Acetylide-Bridged Trigold-JohnPhos Species. Chem.-Eur. J. 2020, 26, 8810-8818. [CrossRef] [PubMed]

17. Siemsen, P.; Livingston, R.C.; Diederich, F. Acetylenic coupling: A powerful tool in molecular construction. Angew. Chem. Int. Ed. 2000, 39, 2632-2657. [CrossRef]

18. Chernyak, N.; Gevorgyan, V. General and Efficient Copper-Catalyzed Three-Component Coupling Reaction towards Imidazoheterocycles. One-Pot Synthesis of Alpidem and Zolpidem. Angew. Chem. Int. Ed. 2010, 49, 2743-2746. [CrossRef] [PubMed]

19. Su, L.; Dong, J.; Liu, L.; Sun, M.; Qiu, R.; Zhou, Y.; Yin, S.-F. Copper Catalysis for Selective Heterocoupling of Terminal Alkynes. J. Am. Chem. Soc. 2016, 138, 12348-12351. [CrossRef]

20. Dong, X.-Y.; Zhang, Y.-F.; Ma, C.-L.; Gu, Q.-S.; Wang, F.-L.; Li, Z.-L.; Jiang, S.-P.; Liu, X.-Y. A general asymmetric copper-catalysed Sonogashira $\mathrm{C}\left(\mathrm{sp}^{3}\right)-\mathrm{C}(\mathrm{sp})$ coupling. Nat. Chem. 2019, 11, 1158-1166. [CrossRef]

21. Hamada, T.; Ye, X.; Stahl, S.S. Copper-Catalyzed Aerobic Oxidative Amidation of Terminal Alkynes: Efficient Synthesis of Ynamides. J. Am. Chem. Soc. 2008, 130, 833-835. [CrossRef]

22. Hay, A.S. Oxidative couplings of acetylenes. II. J. Org. Chem. 1962, 27, 3320-3321. [CrossRef]

23. Yu, D.; Zhang, Y. Copper- and copper-N-heterocyclic carbene-catalyzed C-H activating carboxylation of terminal alkynes with $\mathrm{CO}_{2}$ at ambient conditions. Proc. Natl. Acad. Sci. USA 2010, 107, 20184-20189. [CrossRef]

24. Manjolinho, F.; Arndt, M.; Goossen, K.; Goossen, L.J. Catalytic C-H Carboxylation of Terminal Alkynes with Carbon Dioxide. ACS Catal. 2012, 2, 2014-2021. [CrossRef]

25. Tachiyama, T.; Yoshida, M.; Aoyagi, T.; Fukuzumi, S. Mechanistic study on dimerization of acetylene with a Nieuwland catalyst. Appl. Organomet. Chem. 2008, 22, 205-210. [CrossRef]

26. Bakhoda, A.; Okoromoba, O.E.; Greene, C.; Boroujeni, M.R.; Bertke, J.A.; Warren, T.H. Three-Coordinate Copper(II) Alkynyl Complex in C-C Bond Formation: The Sesquicentennial of the Glaser Coupling. J. Am. Chem. Soc. 2020, 142, 18483-18490. [CrossRef] [PubMed]

27. Deraedt, C.; Pinaud, N.; Astruc, D. Recyclable Catalytic Dendrimer Nanoreactor for Part-Per-Million CuI Catalysis of "Click" Chemistry in Water. J. Am. Chem. Soc. 2014, 136, 12092-12098. [CrossRef]

28. Fang, Y.; Bao, K.; Zhang, P.; Sheng, H.; Yun, Y.; Hu, S.-X.; Astruc, D.; Zhu, M. Insight into the Mechanism of the CuAAC Reaction by Capturing the Crucial $\mathrm{Au}_{4} \mathrm{Cu}_{4}-\pi$-Alkyne Intermediate. J. Am. Chem. Soc. 2021, 143, 1768-1772. [CrossRef] 
29. Thirumurugan, P.; Matosiuk, D.; Jozwiak, K. Click Chemistry for Drug Development and Diverse Chemical-Biology Applications. Chem. Rev. 2013, 113, 4905-4979. [CrossRef]

30. Chen, J.; Li, K.; Bonson, S.E.; Zimmerman, S.C. A Bioorthogonal Small Molecule Selective Polymeric "Clickase". J. Am. Chem. Soc. 2020, 142, 13966-13973. [CrossRef] [PubMed]

31. Neumann, S.; Biewend, M.; Rana, S.; Binder, W.H. The CuAAC: Principles, Homogeneous and Heterogeneous Catalysts, and Novel Developments and Applications. Macromol. Rapid Commun. 2020, 41, 1900359. [CrossRef] [PubMed]

32. Agrahari, A.K.; Bose, P.; Jaiswal, M.K.; Rajkhowa, S.; Singh, A.S.; Hotha, S.; Mishra, N.; Tiwari, V.K. Cu(I)-Catalyzed Click Chemistry in Glycoscience and Their Diverse Applications. Chem. Rev. 2021, 121, 7638-7956. [CrossRef] [PubMed]

33. Liu, S.; Han, X.; Chai, Y.; Wu, G.; Li, W.; Li, J.; da Silva, I.; Manuel, P.; Cheng, Y.; Daemen, L.L.; et al. Efficient Separation of Acetylene and Carbon Dioxide in a Decorated Zeolite. Angew. Chem. Int. Ed. 2021, 133, 6600-6606. [CrossRef]

34. Chen, S.; Behera, N.; Yang, C.; Dong, Q.; Zheng, B.; Li, Y.; Tang, Q.; Wang, Z.; Wang, Y.; Duan, J. A chemically stable nanoporous coordination polymer with fixed and free $\mathrm{Cu}^{2+}$ ions for boosted $\mathrm{C}_{2} \mathrm{H}_{2} / \mathrm{CO}_{2}$ separation. Nano Res. 2020, 14, 546-553. [CrossRef]

35. He, Y.; Zhang, Z.; Xiang, S.; Wu, H.; Fronczek, F.R.; Zhou, W.; Krishna, R.; O'Keeffe, M.; Chen, B. High Separation Capacity and Selectivity of C2 Hydrocarbons over Methane within a Microporous Metal-Organic Framework at Room Temperature. Chem.-Eur. J. 2012, 18, 1901-1904. [CrossRef] [PubMed]

36. Hu, Y.; Xiang, S.; Zhang, W.; Zhang, Z.; Wang, L.; Bai, J.; Chen, B. A new MOF-505 analog exhibiting high acetylene storage Chem. Commun. 2009, 48, 7551-7553. [CrossRef] [PubMed]

37. Zhang, J.-W.; Hu, M.-C.; Li, S.-N.; Jiang, Y.-C.; Qu, P.; Zhai, Q.-G. Assembly of $\left[\mathrm{Cu}_{2}(\mathrm{COO})_{4}\right]$ and $\left[\mathrm{M}_{3}\left(\mu_{3}-\mathrm{O}\right)(\mathrm{COO})_{6}\right](\mathrm{M}=\mathrm{Sc}, \mathrm{Fe}$, $\mathrm{Ga}$, and $\mathrm{In}$ ) building blocks into porous frameworks towards ultra-high $\mathrm{C}_{2} \mathrm{H}_{2} / \mathrm{CO}_{2}$ and $\mathrm{C}_{2} \mathrm{H}_{2} / \mathrm{CH}_{4}$ separation performance. Chem. Commun. 2018, 54, 2012-2015. [CrossRef] [PubMed]

38. Lang, H.; Jakob, A.; Milde, B. Copper(I) Alkyne and Alkynide Complexes. Organometallics 2012, 31, 7661-7693. [CrossRef]

39. Perez, P.J.; Dias-Requejo, M.M. Copper Organometallics, in Comprehensive Organometallic Chemistry III; Elsevier: Amsterdam, The Netherlands, 2007; Volume 2, pp. 153-195.

40. Koehler, K.; Eichhorn, J.; Meyer, F.; Vidovic, D. Dicopper(I) Oxalate Complexes Stabilized by Lewis Bases: Potential Precursors for Copper Deposition. Organometallics 2003, 22, 4426-4432. [CrossRef]

41. Doppelt, P.; Baum, T.H. Alkyne complexes of copper(I) (1,1,1,5,5,5-hexafluoro-2,4-pentanedionato): Syntheses and characterization of ( $\eta^{2}$-bis(trimethylsilyl)acetylene) copper(I) (hfac), ( $\mu-\eta^{2}$-bis(trimethylsilyl)acetylene) bis(copper(I) (hfac)) and a series of $\left(\eta^{2}-\right.$ alkyne) $\mathrm{Cu}(\mathrm{hfac})$ complexes. J. Organomet. Chem. 1996, 517, 53-62.

42. Dias, H.V.R.; Richey, S.A.; Diyabalanage, H.V.K.; Thankamani, J. Copper(I) complexes supported by a heavily fluorinated bis(pyrazolyl)borate: Syntheses and characterization of $\left[\mathrm{H}_{2} \mathrm{~B}\left(3,5-\left(\mathrm{CF}_{3}\right)_{2} \mathrm{Pz}\right)_{2}\right] \mathrm{CuL}$ (where $\mathrm{L}=\mathrm{PPh}_{3}, \mathrm{NCCH}_{3}, \mathrm{HCCPh}, \mathrm{H}_{2} \mathrm{CCHPh}$ ) and $\left\{\left[\mathrm{H}_{2} \mathrm{~B}\left(3,5-\left(\mathrm{CF}_{3}\right)_{2} \mathrm{Pz}\right)_{2}\right] \mathrm{Cu}\right\}_{2}(1,5-\mathrm{COD})$. J. Organomet. Chem. 2005, 690, 1913-1922. [CrossRef]

43. Dias, H.V.R.; Flores, J.A.; Wu, J.; Kroll, P. Monomeric Copper(I), Silver(I), and Gold(I) Alkyne Complexes and the Coinage Metal Family Group Trends. J. Am. Chem. Soc. 2009, 131, 11249-11255. [CrossRef] [PubMed]

44. Das, A.; Dash, C.; Celik, M.A.; Yousufuddin, M.; Frenking, G.; Dias, H.V.R. Tris(alkyne) and Bis(alkyne) Complexes of Coinage Metals: Synthesis and Characterization of (cyclooctyne $)_{3} \mathrm{M}^{+}(\mathrm{M}=\mathrm{Cu}, \mathrm{Ag})$ and (cyclooctyne $)_{2} \mathrm{Au}^{+}$and $\mathrm{Coinage} \mathrm{Metal}(\mathrm{M}=\mathrm{Cu}$, Ag, Au) Family Group Trends. Organometallics 2013, 32, 3135-3144. [CrossRef]

45. Das, A.; Dash, C.; Yousufuddin, M.; Dias, H.V.R. Coordination and Ligand Substitution Chemistry of Bis(cyclooctyne)copper(I). Organometallics 2014, 33, 1644-1650. [CrossRef]

46. Parasar, D.; Almotawa, R.M.; Jayaratna, N.B.; Ceylan, Y.S.; Cundari, T.R.; Omary, M.A.; Dias, H.V.R. Synthesis, Photophysical Properties, and Computational Analysis of Di- and Tetranuclear Alkyne Complexes of Copper(I) Supported by a Highly Fluorinated Pyrazolate. Organometallics 2018, 37, 4105-4118. [CrossRef]

47. Parasar, D.; Ponduru, T.T.; Noonikara-Poyil, A.; Jayaratna, N.B.; Dias, H.V.R. Acetylene and terminal alkyne complexes of copper(I) supported by fluorinated pyrazolates: Syntheses, structures, and transformations. Dalton Trans. 2019, 48, 15782-15794. [CrossRef]

48. Lakhi, J.S.; Patterson, M.R.; Dias, H.V.R. Coinage metal metallacycles involving a fluorinated 3,5-diarylpyrazolate. New J. Chem. 2020, 44, 14814-14822. [CrossRef]

49. Patterson, M.; Dias, H.V.R. Tetranuclear and trinuclear copper(I) pyrazolates as catalysts in copper mediated azide-alkyne cycloadditions (CuAAC). Dalton Trans. 2022, 51, 375-383. [CrossRef]

50. Dias, H.V.R.; Polach, S.A.; Wang, Z. Coinage metal complexes of 3,5-bis(trifluoromethyl)pyrazolate ligand. Synthesis and characterization of $\left\{\left[3,5-\left(\mathrm{CF}_{3}\right)_{2} \mathrm{Pz}\right] \mathrm{Cu}\right\}_{3}$ and $\left\{\left[3,5-\left(\mathrm{CF}_{3}\right)_{2} \mathrm{Pz}\right] \mathrm{Ag}\right\}_{3}$. J. Fluorine Chem. 2000, 103, 163-169. [CrossRef]

51. Lang, H.; Koehler, K.; Blau, S. $\eta^{2}$-Alkyne copper(I) and silver(I) compounds; from polymeric $\left[M^{I} R\right]_{n}$ to monomeric $\left[M^{I} R\right]$ units $(\mathrm{M}=\mathrm{Cu}, \mathrm{Ag})$. Coord. Chem. Rev. 1995, 143, 113-168. [CrossRef]

52. Liang, L.; Astruc, D. The copper(I)-catalyzed alkyne-azide cycloaddition (CuAAC) "click" reaction and its applications. An overview. Coord. Chem. Rev. 2011, 255, 2933-2945. [CrossRef]

53. Bauer, H.; Faust, J.; Rolf, F.; Johannes, F.; Krüerke, U.; Kunz, M.; Somer, H.M. (Eds.) Cu Organocopper Compounds: Compounds with Ligands Bonded by Two C. Atoms; Springer: Berlin/Heidelberg, Germany, 1987; Volume 4, pp. 1-101.

54. Jardine, F.H. Copper(I) Complexes. In Advances in Inorganic Chemistry and Radiochemistry; Emeléus, H.J., Sharpe, A.G., Eds.; Academic Press: Cambridge, MA, USA, 1975; Volume 17, pp. 115-163.

55. Thompson, J.S.; Whitney, J.F. Copper(I) complexes with unsaturated small molecules. Preparation and structural characterization of copper(I)-di-2-pyridylamine complexes with olefins, acetylene, and carbon monoxide. Inorg. Chem. 1984, 23, 2813-2819. [CrossRef] 
56. Munakata, M.; Kitagawa, S.; Kawada, I.; Maekawa, M.; Shimono, H. Synthesis, formation constants and structures of ternary copper(I) complexes with 1,10-phenanthroline and alkynes. J. Chem. Soc. Dalton Trans. 1992, 2225-2230. [CrossRef]

57. Thompson, J.S.; Whitney, J.F. Preparation and structural characterization of acetylene(2,2'-dipyridylamine)copper(I) tetrafluoroborate. J. Am. Chem. Soc. 1983, 105, 5488-5490. [CrossRef]

58. Mykhalichko, B.M.; Mys'kiv, M.G.; Davydov, V.N. Acetylene as a bridging $\pi$-ligand. Synthesis and crystal structure of $\mathrm{NH}_{4}\left[\mathrm{Cu}_{8} \mathrm{Cl}_{9}\left(\mathrm{C}_{2} \mathrm{H}_{2}\right)_{4}\right] \cdot 2 / 5\left\{\left[\mathrm{Cu}\left(\mathrm{H}_{2} \mathrm{O}\right)_{2}\right]^{+}\left[\mathrm{CuCl}_{2}\right]^{-} \cdot \mathrm{H}_{2} \mathrm{O}\right\}$. Zh. Neorg. Khim. 1999, 44, 411-414.

59. Mykhalichko, B.M.; Mys'kiv, M.G.; Aksel'rud, L.G. Acetylene as a bridging П-ligand: Synthesis and crystal structure of $\mathrm{NH}_{4} \mathrm{Cu}_{3} \mathrm{Cl}_{4} \cdot \mathrm{C}_{2} \mathrm{H}_{2}$. Koord. Khim. 1993, 19, 722-726.

60. Osechkin, S.I.; Mys'kiv, M.G.; Zavalii, P.Y.; Sobolev, A.N. X-ray investigation of copper(I) chloride $\pi$-complexes with bidentate acetylene in the $\mathrm{CuCl}-\mathrm{HCl}-\mathrm{C}_{2} \mathrm{H}_{2}-\mathrm{KCl}-\mathrm{H}_{2} \mathrm{O}$ system. Metalloorg. Khim. 1991, 4, 997-1003.

61. Hyman, M.R.; Arp, D.J. Quantification and removal of some contaminating gases from acetylene used to study gas-utilizing enzymes and microorganisms. Appl. Environ. Microbiol. 1987, 53, 298-303. [CrossRef]

62. Trotuş, I.-T.; Zimmermann, T.; Schüth, F. Catalytic Reactions of Acetylene: A Feedstock for the Chemical Industry Revisited. Chem. Rev. 2014, 114, 1761-1782. [CrossRef]

63. ACS. Spectroscopy Resources, ACS Division of Organic Chemistry. Available online: https://organicchemistrydata.org/links/ \#spectroscopy_resources (accessed on 7 December 2021).

64. Fast, H.; Welsh, H.L. High-resolution Raman spectra of acetylene, acetylene-d1, and acetylene-d2. J. Mol. Spectrosc. 1972, 41, 203-221. [CrossRef]

65. Chatt, J.; Duncanson, L.A. Olefin coördination compounds. III. Infrared spectra and structure: Attempted preparation of acetylene compounds. J. Chem. Soc. 1953, 2939-2947. [CrossRef]

66. Dewar, M.J.S. A review of the $\pi$-complex theory. Bull. Soc. Chim. Fr. 1951, 18, C71-C79.

67. Dias, H.V.R.; Wang, Z.; Jin, W. Synthesis and Chemistry of [Hydrotris(3,5-bis(trifluoromethyl)pyrazolyl)borato]silver(I) Complexes. Inorg. Chem. 1997, 36, 6205-6215. [CrossRef]

68. Wieder, N.L.; Carroll, P.J.; Berry, D.H. Structure and Reactivity of Acetylene Complexes of Bis(imino)pyridine Ruthenium(0). Organometallics 2011, 30, 2125-2136. [CrossRef]

69. Bustelo, E.; Carbó, J.J.; Lledós, A.; Mereiter, K.; Puerta, M.C.; Valerga, P. First X-ray Characterization and Theoretical Study of $\pi$-Alkyne, Alkynyl-Hydride, and Vinylidene Isomers for the Same Transition Metal Fragment $\left.\left[\mathrm{Cp}{ }^{*} \mathrm{Ru}_{(\mathrm{PEt}}\right)_{2}\right]^{+}$. J. Am. Chem. Soc. 2003, 125, 3311-3321. [CrossRef] [PubMed]

70. Pörschke, K.R.; Tsay, Y.-H.; Krüger, C. Ethynebis(triphenylphosphane)nickel(0). Angew. Chem. Int. Ed. 1985, 24, 323-324. [CrossRef]

71. Available online: https:// webbook.nist.gov/cgi/cbook.cgi?ID=C74862\&Mask=800 (accessed on 7 December 2021).

72. McMullan, R.K.; Kvick, Å.; Popelier, P. Structures of cubic and orthorhombic phases of acetylene by single-crystal neutron diffraction. Acta Crystallogr. Sect. B 1992, 48, 726-731. [CrossRef]

73. Albright, T.A.; Hoffmann, R.; Thibeault, J.C.; Thorn, D.L. Ethylene complexes. Bonding, rotational barriers, and conformational preferences. J. Am. Chem. Soc. 1979, 101, 3801-3812. [CrossRef]

74. Allen, F.H.; Kennard, O.; Watson, D.G.; Brammer, L.; Orpen, A.G.; Taylor, R. Tables of bond lengths determined by X-ray and neutron diffraction. Part 1. Bond lengths in organic compounds. J. Chem. Soc. Perkin Trans. 2 1987, S1-S19. [CrossRef]

75. Groom, C.R.; Bruno, I.J.; Lightfoot, M.P.; Ward, S.C. The Cambridge Structural Database. Acta Cryst. 2016, B72, 171-179. [CrossRef]

76. Yasuda, H.; Yamamoto, H.; Arai, T.; Nakamura, A.; Chen, J.; Kai, Y.; Kasai, N. Facile synthesis and stereochemistry of alkyne complexes of $\mathrm{Cp}_{2} \mathrm{MH}$ and $\mathrm{Cp}_{2} \mathrm{MCH}_{2} \mathrm{CH}_{2} \mathrm{R}$ (M = niobium, tantalum). Organometallics 1991, 10, 4058-4066. [CrossRef]

77. Hill, A.F.; Tshabang, N.; Willis, A.C. Poly(methimazolyl)borate alkyne complexes of molybdenum and tungsten. Eur. J. Inorg. Chem. 2007, 3781-3785. [CrossRef]

78. Kiplinger, J.L.; Arif, A.M.; Richmond, T.G. Influence of $\pi$-Conflict on Structure and Reactivity. Comparative Study of $\eta^{2}$-Nitriles and $\eta^{2}$-Alkynes as Four-Electron Donor Ligands in Tungsten(II) Fluoride Carbonyl Systems. Organometallics 1997, 16, 246-254. [CrossRef]

79. Ziegler, T.; Rauk, A. A theoretical study of the ethylene-metal bond in complexes between copper(1+), silver(1+), gold(1+), platinum(0) or platinum(2+) and ethylene, based on the Hartree-Fock-Slater transition-state method. Inorg. Chem. 1979, 18, 1558-1565. [CrossRef]

80. Mitoraj, M.P.; Michalak, A.; Ziegler, T. A Combined Charge and Energy Decomposition Scheme for Bond Analysis. J. Chem. Theory Comput. 2009, 5, 962-975. [CrossRef] [PubMed]

81. Titov, A.A.; Larionov, V.A.; Smolyakov, A.F.; Godovikova, M.I.; Titova, E.M.; Maleev, V.I.; Shubina, E.S. Interaction of a trinuclear copper(I) pyrazolate with alkynes and carbon-carbon triple bond activation. Chem. Commun. 2019, 55, 290-293. [CrossRef]

82. Huisgen, R.; Szeimies, G.; Moebius, L. 1,3-Dipolar cycloadditions. XXXII. Kinetics of the addition of organic azides to carboncarbon multiple bonds. Chem. Ber. 1967, 100, 2494-2507. [CrossRef]

83. Trofimenko, S. Recent advances in poly(pyrazolyl)borate (scorpionate) chemistry. Chem. Rev. 1993, 93, 943-980. [CrossRef]

84. Dias, H.V.R.; Lovely, C.J. Carbonyl and Olefin Adducts of Coinage Metals Supported by Poly(pyrazolyl)borate and Poly(pyrazolyl)alkane Ligands and Silver Mediated Atom Transfer Reactions. Chem. Rev. 2008, 108, 3223-3238. [CrossRef]

85. Wang, T.-H.; Wu, F.-L.; Chiang, G.-R.; He, S.-T.; Lo, Y.-H. Preparation of ruthenium azido complex containing a Tp ligand and ruthenium-catalyzed cycloaddition of organic azides with alkynes in organic and aqueous media: Experimental and computational studies. J. Organomet. Chem. 2014, 774, 57-60. [CrossRef] 
86. Munoz-Molina, J.M.; Belderrain, T.R.; Perez, P.J. Trispyrazolylborate coinage metals complexes: Structural features and catalytic transformations. Coord. Chem. Rev. 2019, 390, 171-189. [CrossRef]

87. Cano, I.; Nicasio, M.C.; Perez, P.J. Copper(I) complexes as catalysts for the synthesis of N-sulfonyl-1,2,3-triazoles from Nsulfonylazides and alkynes. Org. Biomol. Chem. 2010, 8, 536-538. [CrossRef]

88. Bahsis, L.; Ben El Ayouchia, H.; Anane, H.; Ramirez de Arellano, C.; Bentama, A.; El Hadrami, E.M.; Julve, M.; Domingo, L.R.; Stiriba, S.-E. Clicking azides and alkynes with poly(pyrazolyl)borate-copper(I) catalysts: An experimental and computational study. Catalysts 2019, 9, 687. [CrossRef]

89. Larionov, V.A.; Stashneva, A.R.; Titov, A.A.; Lisov, A.A.; Medvedev, M.G.; Smol'yakov, A.F.; Tsedilin, A.M.; Shubina, E.S.; Maleev, V.I. Mechanistic study in azide-alkyne cycloaddition (CuAAC) catalyzed by bifunctional trinuclear copper(I) pyrazolate complex: Shift in rate-determining step. J. Catal. 2020, 390, 37-45. [CrossRef]

90. Noonikara-Poyil, A.; Munoz-Castro, A.; Boretskyi, A.; Mykhailiuk, P.K.; Dias, H.V.R. When SF 5 outplays $\mathrm{CF}_{3}$ : Effects of pentafluorosulfanyl decorated scorpionates on copper. Chem. Sci. 2021, 12, 14618-14623. [CrossRef]

91. Noonikara-Poyil, A.; Cui, H.; Yakovenko, A.A.; Stephens, P.W.; Lin, R.-B.; Wang, B.; Chen, B.; Dias, H.V.R. A Molecular Compound for Highly Selective Purification of Ethylene. Angew. Chem. Int. Ed. 2021, 133, 27390-27394. [CrossRef]

92. Thomas, J.; John, J.; Parekh, N.; Dehaen, W. A Metal-Free Three-Component Reaction for the Regioselective Synthesis of 1,4,5-Trisubstituted 1,2,3-Triazoles. Angew. Chem. 2014, 126, 10319-10323. [CrossRef]

93. Krause, L.; Herbst-Irmer, R.; Sheldrick, G.M.; Stalke, D. Comparison of silver and molybdenum microfocus X-ray sources for single-crystal structure determination. J. Appl. Crystallogr. 2015, 48, 3-10. [CrossRef] [PubMed]

94. Sheldrick, G. SHELXT_-Integrated space-group and crystal-structure determination. Acta Crystallogr. Sect. A Found. Adv. 2015, 71, 3-8. [CrossRef]

95. Sheldrick, G. Crystal structure refinement with SHELXL. Acta Crystallogr. Sect. C Struct. Chem. 2015, 71, 3-8. [CrossRef]

96. Dolomanov, O.V.; Bourhis, L.J.; Gildea, R.J.; Howard, J.A.K.; Puschmann, H. OLEX2: A complete structure solution, refinement and analysis program. J. Appl. Crystallogr. 2009, 42, 339-341. [CrossRef] 